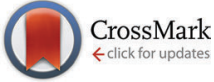

Cite this: New J. Chem., 2016, 40,7943

Received (in Montpellier, France) 17th December 2015, Accepted 25th July 2016

DOI: 10.1039/c5nj03601a

www.rsc.org/njc

\title{
Full characterization and cytotoxic activity of new silver (I) and copper(I) helicates with quaterpyridine $\uparrow$
}

\author{
Ariel Adamski, $\ddagger^{a}$ Marta A. Fik, $\ddagger^{a}$ Maciej Kubicki, ${ }^{a}$ Zbigniew Hnatejko, ${ }^{a}$ Dorota Gurda, ${ }^{b}$ \\ Agnieszka Fedoruk-Wyszomirska, ${ }^{b}$ Eliza Wyszko, ${ }^{b}$ Dariusz Kruszka, \\ Zbigniew Dutkiewicz ${ }^{c}$ and Violetta Patroniak*a
}

\begin{abstract}
The self-assembly of $6,6^{\prime \prime \prime \prime}$-dimethyl- $2,2^{\prime} ; 6^{\prime}, 2^{\prime \prime} ; 6^{\prime \prime}, 2^{\prime \prime \prime}$-quaterpyridine $\mathbf{L}$ with tetrahedral ions of silver(I) and copper(I) leads to the formation of dinuclear double stranded helicates $1-4 .{ }^{1} \mathrm{H}$ NMR studies confirm the stability of each helicate both in $2 \%$ aqueous DMSO solution, which plays the role of a medium in biological studies, and in the cell extract solution. The cytotoxic properties of complexes were examined on two cancerous cell lines: HeLa and T-47D as well as on the non-neoplastic fibroblasts HaCaT by using the MTT assay method. The $I_{50}$ values of cisplatin towards cancerous cell lines are rather comparable. However, the trend of cancerous/healthy cell selectivity is not maintained. One may assume a different mechanism of action. Moreover, it is possible to distinguish the cell death pathway triggered by $\mathrm{Ag}(\mathrm{I})$ and $\mathrm{Cu}(\mathrm{I})$ helicates presented in this study. Flow cytometry, EtBr displacement titrations, CD titrations, DNA melting experiments and DFT calculations were used to characterize the type of interaction and the mechanism of cytotoxic action.
\end{abstract}

\section{Introduction}

The establishment of the fundamental principles of supramolecular chemistry has initiated the revolution in numerous areas of chemistry and biology, thus resulting in new outlooks and perspectives. Research conducted for over half a century, exploiting the main concepts of supramolecular chemistry, selfassembly and molecular recognition, ${ }^{1}$ has proved to be indispensable to explain the key mechanisms in living organisms and to construct supramolecular assemblies. ${ }^{2}$ The use of noncovalent bonds ${ }^{3}$ offers the possibility of designing a wide spectrum of architectures. ${ }^{4}$ The nature of binding has a profound impact on the dynamics and architectures of the selfassembled systems. Coordination bonding ${ }^{5}$ - highly directional and often comparable to the strength of covalent bonds - allows

\footnotetext{
${ }^{a}$ Faculty of Chemistry, Adam Mickiewicz University, Umultowska 89B, Poznań, 61-614, Poland. E-mail: violapat@amu.edu.pl

${ }^{b}$ Institute of Bioorganic Chemistry, Polish Academy of Science, Noskowskiego 12/14, Poznań, 61-704, Poland

${ }^{c}$ Department of Chemical Technology of Drugs, Poznań University of Medical Sciences, Grunwaldzka 6, Poznań, 60-780, Poland

$\dagger$ Electronic supplementary information (ESI) available. CCDC 1060683-1060686. For ESI and crystallographic data in CIF or other electronic format see DOI: 10.1039/c5nj03601a

\$ Ariel Adamski and Marta A. Fik contributed equally to the experimental results given in this work.
}

one to form thermodynamically stable assemblies such as grids, boxes, cylinders or helicates. ${ }^{6-8}$

Helicates are a distinct class of metallosupramolecular complexes with fascinating topologies, ${ }^{9}$ composed of at least one intertwining strand of an organic ligand, which is wrapped around metal ion(s), thus generating a helical axis between metallic knots. ${ }^{10,11}$ The design of helicates requires the consideration of multiple factors. The most important are the stereoelectronic preferences of the metal ions, ligand topology and its flexibility as well as the variation of the spacing groups that link the coordination domains. ${ }^{12}$ Tailoring the ligand structure (type, the number and distribution of donor units) to the geometry of the metal ion is a key parameter in the self-assembly of helicates. Therefore, a ligand should be designed so as to possess an individual donor domain able to coordinate a separate metal ion. ${ }^{13}$ Thus, the formation of helicates is directed by the interplay between the flexibility and rigidity of polydentate ligands. ${ }^{14}$ All these features are satisfied within the frameworks of polypyridine systems, especially those containing the $2,2^{\prime}$-bipyridine motifs. ${ }^{15}$ The coordination linkage of bipyridine units with tetragonal metal ions is a well-known supramolecular synthon in the engineering process of helicates. ${ }^{16}$ In this context, quaterpyridine functions as a bis(bpy) bridging ligand by using two independent bipyridine subunits in the coordination of tetrahedral silver(I) or copper(I) ions. This results in the formation of helical structures. ${ }^{17}$ 
The extraordinary architecture and topology of helicates generate numerous applications, especially in terms of medicinal chemistry, ${ }^{18}$ chiral synthesis, ${ }^{19}$ asymmetric catalysis ${ }^{20}$ as well as the generation of optical devices ${ }^{21}$ and advanced supramolecular materials. ${ }^{22}$ Double-stranded metal helicates are positively charged in their core ${ }^{23}$ which results in their ability to bind the DNA helix and consequently prevents the DNA cleavage by restriction enzymes. ${ }^{24}$ The action of many helical metal-drug complexes is the result of selective molecular recognition of helical structures by enzymes which may lead to their inhibition or formation of metalloenzymes. ${ }^{25}$ In this context, the properties of helicates are not only the result of their purely structural form, but also are amenable to the nature of the metal ion. $\operatorname{Ag}(\mathrm{I})$ ions, excellent templates for the formation of polypyridine helicates, are often used in the fields of medicinal and analytical chemistry. Ag(I) complexes show enhanced bioactivity compared to their simple salts, ${ }^{26}$ which is related to distinct reversible $\mathrm{Ag}-\mathrm{N}$ and $\mathrm{Ag}-\mathrm{O}$ interactions. ${ }^{27}$ Consequently, $\mathrm{Ag}(\mathrm{I})$ compounds find applications in the treatment of epilepsy, nicotine addiction or mental illnesses, ${ }^{28}$ or as agents in the treatment of burn wounds. ${ }^{29}$ Replacement of $\mathrm{Ag}(\mathrm{I})$ ions with $\mathrm{Cu}(\mathrm{I})$ ions in quaterpyridine complexes has no significant effect on their helicity, but substantially modifies the biological properties or provides additional features due to the activity of the $\mathrm{Cu}(\mathrm{I})$ complexes in asymmetric reactions. ${ }^{30} \mathrm{Cu}(\mathrm{I})$ ions are known for their high cytotoxicity as a result of oxidative damage (especially against eukaryotic and prokaryotic cells), ${ }^{31}$ whereas in the form of $\mathrm{Cu}(\mathrm{I})$ helicates may be precisely directed to molecular targets into the diseased cells. Moreover, their cytotoxic effect may be decreased and their mechanism of action may be totally different.

Our previous studies on the coordination properties of dimethylquaterpyridine self-assembled with transition metal ions have resulted in a broad spectrum of architectures, including mono- and poly-nuclear complexes with octahedral metal ions ${ }^{32-34}$ as well as organometallic ${ }^{35}$ and helical complexes. ${ }^{36}$ Simultaneously, our recent studies on the terpyridine complexes of silver(I $)^{37}$ became the inspiration for the design of new helicates of silver(I) and copper(I) with $6,6^{\prime \prime \prime \prime}$-dimethyl- $2,2^{\prime} ; 6^{\prime}, 2^{\prime \prime} ; 6^{\prime \prime}, 2^{\prime \prime \prime}$-quaterpyridine L (Fig. 1).

Herein, we would like to present new crystal structures of $\left[\mathrm{Ag}_{2} \mathbf{L}_{2}\left(\mathrm{CF}_{3} \mathrm{SO}_{3}\right)_{2}\right](\mathbf{1}),\left[\mathrm{Ag}_{2} \mathbf{L}_{2}\left(\mathrm{PF}_{6}\right)_{2}\right](2),\left[\mathrm{Cu}_{2} \mathbf{L}_{2}\left(\mathrm{CF}_{3} \mathrm{SO}_{3}\right)_{2}\right](3)$, and $\left[\mathrm{Cu}_{2} \mathbf{L}_{2}\left(\mathrm{BF}_{4}\right)_{2}\right](\mathbf{4})$, their synthesis, characterization and luminescence studies. However, the main emphasis in this project is put on the investigation of their cytostatic effect towards HeLa and T-47D cancer cell lines as well as non-neoplastic fibroblast

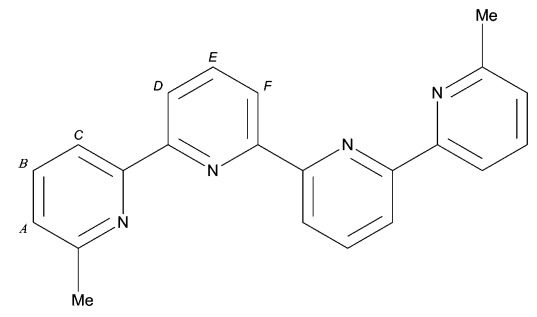

Fig. 1 Schematic representation of ligand $\mathbf{L}$.
HaCat cells. In addition, we carry out DNA binding experiments, by using circular dichroism (CD), competitive binding fluorescence measurements and molecular docking with DNA as well as flow cytometry. Our study represents the first example of the biological evaluation of the quaterpyrdine complexes of $\operatorname{Ag}(\mathrm{I})$ and $\mathrm{Cu}(\mathrm{I})$.

\section{Results and discussion}

\section{${ }^{1} \mathrm{H}$ NMR, FT-IR and ESI-MS analyses of $L$ and 1-4}

The ${ }^{1} \mathrm{H}$ NMR spectrum of free ligand $\mathbf{L}$ shows the presence of a set of seven signals in the range $\delta 8.69-2.69 \mathrm{ppm}$, assigned to 18 protons in the ligand molecule (Fig. S1, ESI $\dagger$ ). The intensity of signals in the spectra of complexes 1-4 is proportional to the number of atoms of hydrogen in ligand $\mathbf{L}$ both in aromatic and aliphatic regions. In the aliphatic region each complex (1-4) generates one sharp singlet centered at $\delta=1.8 \mathrm{ppm}$, which is assigned to 12 protons derived from four methyl groups of coordinated ligand molecules. The upfield shift of the signal from methyl groups in complexes in comparison to free ligand $\mathbf{L}$ is of about $\Delta \delta=0.9 \mathrm{ppm}$, which is the result of the complexation process. The same effect of signal shielding is observed in the aromatic region for each of the 1-4 systems. A set of five signals is presented which corresponds to 24 protons from two quaterpyridine scaffolds in helical architectures (Fig. S2, ESI $\dagger$ ).

The helical form of complexes 1-4 was confirmed by electrospray ionization mass analysis. Each complex shows the presence of two sets of peaks: $\left[M_{2} \mathbf{L}_{2}\right]^{2+}$ and $\left[M_{2} \mathbf{L}_{2}(X)\right]^{+}$(where $M$ is the cation of metal and $\mathrm{X}$ is a counterion). A detailed analysis of the isotopic distribution of both peaks leads to the conclusion that helical form of complexes 1-4 is rather stable even under harsh conditions of the measurements, whereas the ratio of peaks $\left[\mathrm{M}_{2} \mathbf{L}_{2}\right]^{2+}$ to $\left[\mathrm{M}_{2} \mathbf{L}_{2}(\mathrm{X})\right]^{+}$depends on the applied cone voltage (Fig. S3, ESI $\dagger$ ). ${ }^{38}$

As well, FT-IR spectra are in good agreement with the solid state structures and are described in detail in Fig. S4, ESI $†$.

\section{Description of crystal structures}

All four complexes are two-centered with $\mathbf{M}_{2} \mathbf{L}_{2}$ constitution (Fig. 2-5). The metal ions are four-coordinated, in a heavily distorted tetrahedral fashion (largest $\mathrm{N}-\mathrm{M}-\mathrm{N}$ angles are in all molecules around $140^{\circ}$ ). All $\mathrm{N}$ atoms of ligand molecules are involved in the coordination, and every ligand coordinates to both metal cations (two $\mathrm{N}$ atoms with one metal, two - with the other). Both $\mathrm{Cu}-\mathrm{N}$ and $\mathrm{Ag}-\mathrm{N}$ distances are reasonably similar (2.012-2.079 $\AA$ for the former ones, 2.260-2.365 $\AA$ for the latter).

In three out of four cases $(\mathbf{1}, \mathbf{2}$ and 4$)$ the complex molecules are $C_{2}$-symmetrical. In $\mathbf{1}$ and $\mathbf{4}$ a twofold axis passes through the two $\mathrm{Ag}$ cations (so one ligand molecule is symmetry-independent); in 2 the $C_{2}$ axis halves both ligand molecules, and it runs through the middle points of the central $\mathrm{C}-\mathrm{C}$ bonds.

In order to allow for such constrained geometry, the ligand molecules are significantly twisted, the dihedral angle between the planes of terminal rings is as high as $60-70^{\circ}$. Table 1 lists the values of individual dihedral angles. The relatively compact 


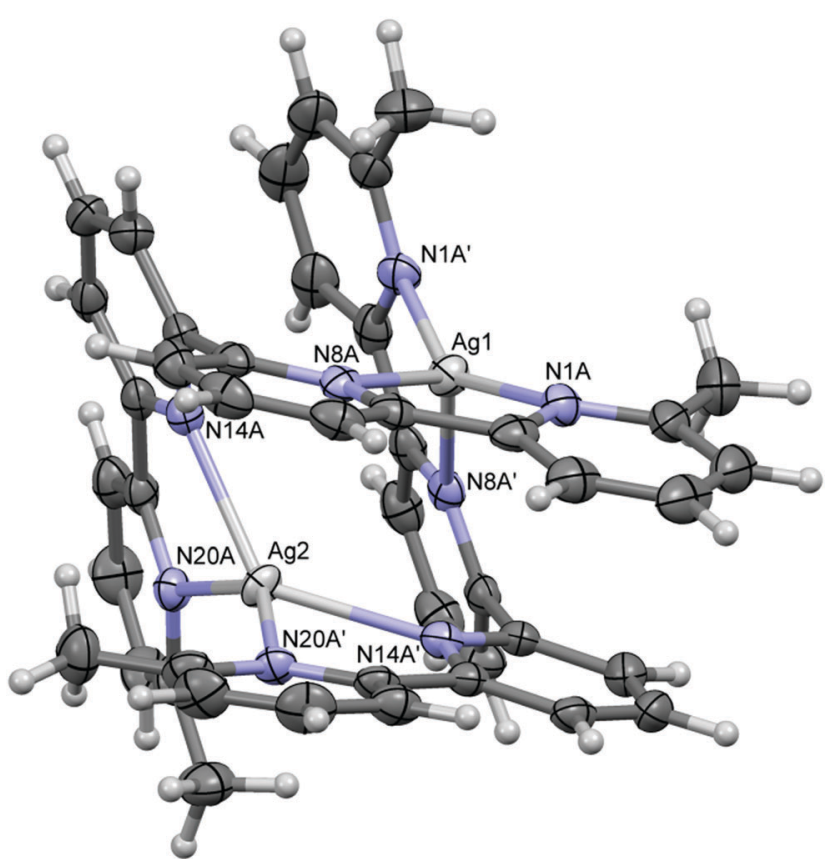

Fig. 2 Anisotropic ellipsoid representation of complex 1; ellipsoids are drawn at the $50 \%$ probability level; hydrogen atoms are shown as spheres of arbitrary radii. The primed atoms are related to the unprimed ones by symmetry operation $1 / 2-x, y, 1-z$

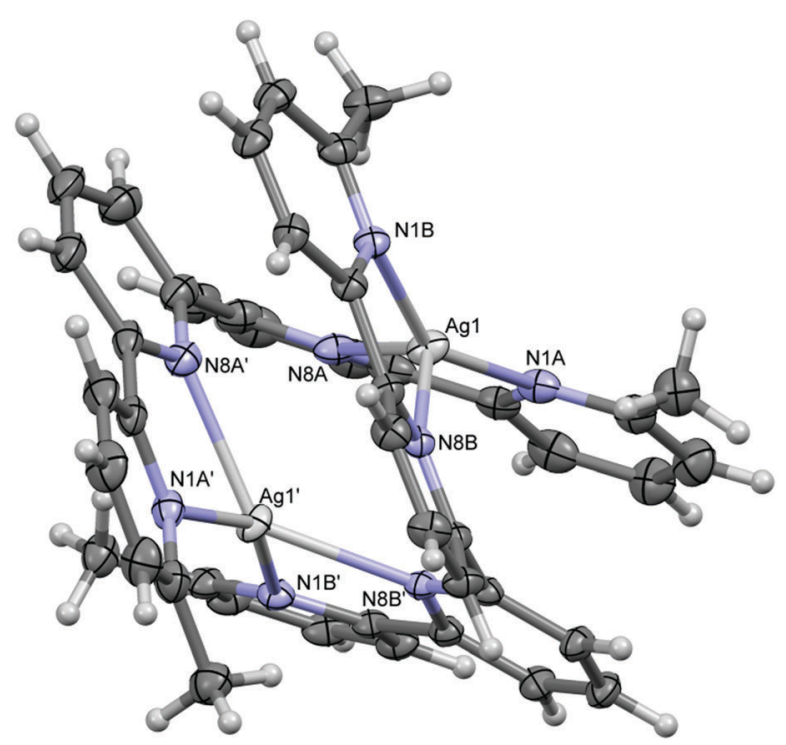

Fig. 3 Anisotropic ellipsoid representation of complex 2; ellipsoids are drawn at the $50 \%$ probability level; hydrogen atoms are shown as spheres of arbitrary radii. The primed atoms are related to the unprimed ones by symmetry operation $1 / 2-x, y,-z$.

geometry of the complexes is additionally enforced by intramolecular $\pi \cdots \pi$ interactions (the distance between centroids of approximately parallel rings from different ligand molecules is around 3.6 ̊). In the crystal structures the electrostatic interactions are dominant; in the structure of 2 the voids in the crystal structure are filled with electron density, described as disordered water molecules (Fig. 3).

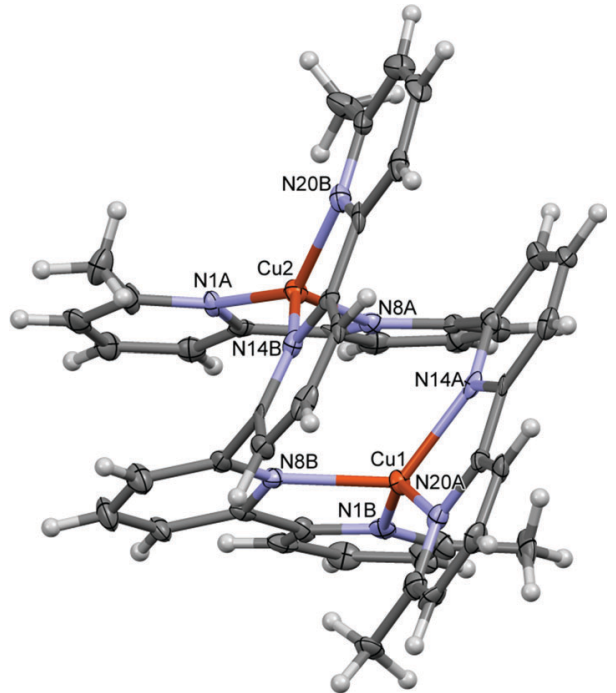

Fig. 4 Anisotropic ellipsoid representation of complex 3; ellipsoids are drawn at the $50 \%$ probability level; hydrogen atoms are shown as spheres of arbitrary radii.

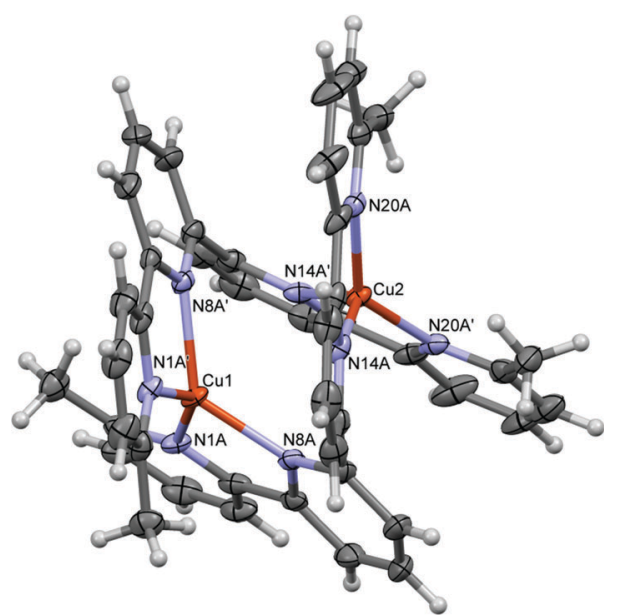

Fig. 5 Anisotropic ellipsoid representation of complex 4; ellipsoids are drawn at the $50 \%$ probability level; hydrogen atoms are shown as spheres of arbitrary radii. The primed atoms are related to the unprimed ones by symmetry operation $-x, y, 3 / 2-z$.

Table 1 Dihedral angles $\left({ }^{\circ}\right)$ between the planes of aromatic rings in $\mathbf{L}$ molecules

\begin{tabular}{lllllll}
\hline & 1 & 2 & & 3 & 4 \\
\hline A/B & $11.1(2)$ & $17.2(2)$ & $17.2(2)$ & $11.92(5)$ & $18.00(8)$ & $15.6(2)$ \\
B/C & $62.56(9)$ & $44.7(1)$ & $45.96(9)$ & $64.2(1)$ & $61.8(1)$ & $54.76(9)$ \\
C/D & $11.7(2)$ & $17.2(2)$ & $17.2(2)$ & $4.3(1)$ & $7.3(1)$ & $7.5(2)$ \\
A/D & $73.9(1)$ & $60.46(9)$ & $53.88(9)$ & $69.9(1)$ & $76.9(1)$ & $66.89(9)$
\end{tabular}

\section{Electronic absorption spectra and luminescence properties}

UV-Vis spectral data of $\mathrm{Ag}(\mathrm{I})$ complexes 1 and $2, \mathrm{Cu}(\mathrm{I})$ complexes 3 and $\mathbf{4}$, and ligand $\mathbf{L}$ were obtained in pure $\mathrm{CH}_{3} \mathrm{CN}$ and $2 \%$ aqueous DMSO solutions. In the acetonitrile solution, the free quaterpyridine ligand $\mathbf{L}$ shows two bands $\left(\varepsilon>10^{4} \mathrm{~L} \mathrm{~mol}^{-1} \mathrm{~cm}^{-1}\right)$, 


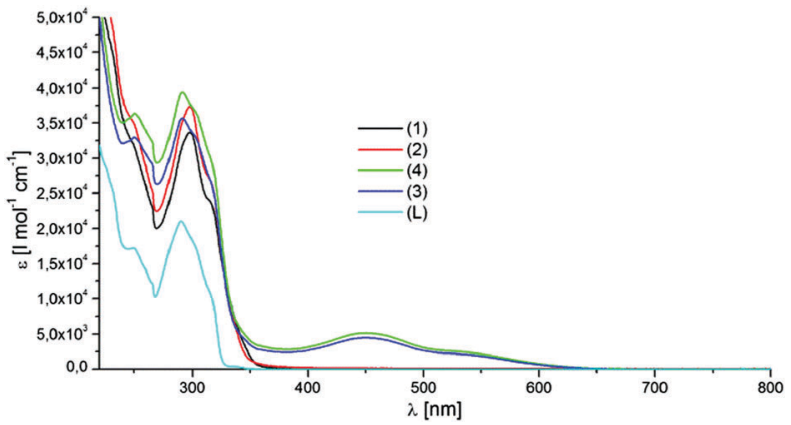

Fig. 6 Electronic absorption spectra of studied compounds in ACN solution at room temperature.

with maxima at 250 and $290.0 \mathrm{~nm}$ assigned to intraligand transition. The absorption spectra of both complexes 1 and 2 display absorption bands at $298 \mathrm{~nm}$. These bands are redshifted, relative to ligand $\mathbf{L}$ (Fig. 6, Table 2).

UV-Vis absorption spectra of the $\mathrm{Cu}(\mathrm{I})$ quaterpyridine complexes $\mathbf{3}$ and $\mathbf{4}$ are composed of two high energy bands and one broad low energy band. The high energy absorption bands peaking at 250.5 and $291.5 \mathrm{~nm}$ are associated with ligand-centered transitions. The weak absorption bands of $\mathbf{3}$ and $\mathbf{4}$ maximized at 450 and $451 \mathrm{~nm}$, respectively, are caused by a charge transfer mechanism, and can be identified as the metal to ligand charge transfer (MLCT) transitions. Similar assignments have also been made in the related copper(I) pyridine systems..$^{39}$ The absorption spectra of the ligand and the complexes in $2 \%$ aqueous DMSO solution are shown in Fig. 7. Peak wavelengths and their absorption coefficients are given in Table 2.

The absorption maxima are red-shifted when increasing the polarity of the solvent. The Stokes shifts (differences between absorption edges and emission peaks) are lowest in the cases of $\mathbf{1}$ and 2 and highest for 3 and $\mathbf{4}$ both in $\mathrm{CH}_{3} \mathrm{CN}$ and $2 \%$ aqueous DMSO solutions. Photoluminescence studies of ligand $\mathbf{L}$ and their complexes were carried out at room temperature.

Upon photo-excitation at $\sim 300 \mathrm{~nm}$ solutions of all complexes give a broad emission band with maxima at $\sim 355$ or $\sim 360 \mathrm{~nm}$ (Fig. 9 and 10). In the acetonitrile solution ligand $\mathbf{L}$ excited at $290 \mathrm{~nm}$ displays luminescence with the emission maximum at $342.6 \mathrm{~nm}$ (Fig. 8), which can be presumed that the peak originates from intraligand transition. The intense emissions of all complexes exhibit a red shift compared to that of the corresponding free ligand $\mathbf{L}$. Complexes 1-4 show similar

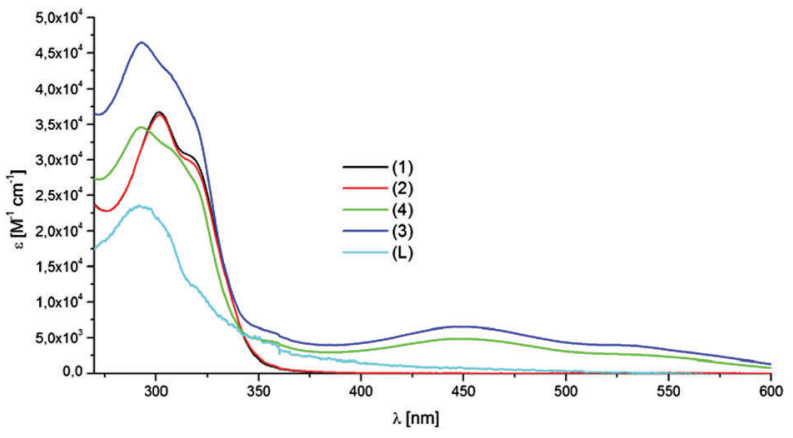

Fig. 7 Electronic absorption spectra of studied compounds in $2 \%$ aqueous DMSO solution at room temperature.

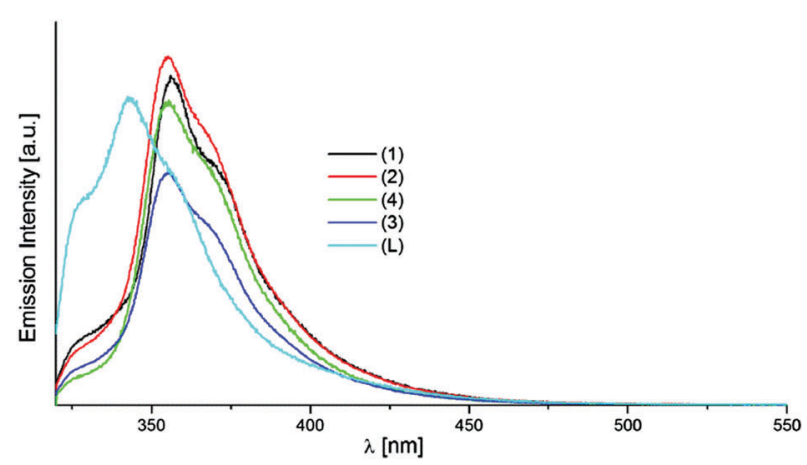

Fig. 8 Emission spectra of ACN solutions of 1-4 complexes and ligand $\mathbf{L}$ at room temperature.

emission spectra. Upon excitation at $292 \mathrm{~nm}$ emission is observed in compounds 3 and $\mathbf{4}$ at $\sim 355 \mathrm{~nm}$. Compounds 1 and 2 exhibit peaks at $356 \mathrm{~nm}$ and $354.8 \mathrm{~nm}$, respectively $\left(\lambda_{\mathrm{ex}}=298 \mathrm{~nm}\right)$.

The emission spectra of compounds 1-4 in $2 \%$ aqueous DMSO solution present emissions at about $360 \mathrm{~nm}\left(\lambda_{\mathrm{ex}}=301\right.$ and $293 \mathrm{~nm}$, Table 2, Fig. 9).

The emission bands are blue-shifted compared to the corresponding ligand $\mathbf{L}\left(\lambda_{\mathrm{em}}=366 \mathrm{~nm}, \lambda_{\mathrm{ex}}=292 \mathrm{~nm}\right)$. The red or blue shifted emissions of complexes 1-4, in both solutions, may be ascribed to the intraligand charge transitions modified by the coordination of the $\mathrm{Ag}(\mathrm{I})$ and $\mathrm{Cu}(\mathrm{I})$ metal ions. ${ }^{40,41}$

Luminescence quantum yields $(\Phi)$ for all compounds (Table 2) were determined relative to a reference luminophore solution of anthracene. The quantum yield is dependent on the medium and the values of emission quantum yields are the

Table 2 The absorption and emission data of complexes 1-4 and quaterpyridine ligand $\mathbf{L}$

\begin{tabular}{|c|c|c|c|c|c|}
\hline Complex & Medium & Absorption $\lambda / \mathrm{nm}\left(\varepsilon \mathrm{M}^{-1} \mathrm{~cm}^{-1}\right)$ & Emission (excitation) $\lambda / \mathrm{nm}$ & $\Delta E_{\text {abs-em }} / \mathrm{cm}^{-1}$ & $\Phi_{\mathrm{em}}$ \\
\hline \multirow[t]{2}{*}{1} & ACN & $298.0(33645)$ & $356.0(298)$ & 5456 & $5.52 \times 10^{-2}$ \\
\hline & $\mathrm{H}_{2} \mathrm{O}-\mathrm{DMSO}$ & $301.2(36740)$ & $360.8(301)$ & 5484 & $2.09 \times 10^{-2}$ \\
\hline \multirow[t]{2}{*}{2} & $\mathrm{ACN}$ & $298.0(37340)$ & $354.8(298)$ & 5372 & $5.27 \times 10^{-2}$ \\
\hline & $\mathrm{H}_{2} \mathrm{O}-\mathrm{DMSO}$ & $302.2(36372)$ & $362.6(302)$ & 5512 & $2.42 \times 10^{-2}$ \\
\hline \multirow[t]{2}{*}{3} & ACN & 250.5 (32 950); 291.5 (35 655); 451.0 (4455) & $355.2(292)$ & 6152 & $3.78 \times 10^{-2}$ \\
\hline & $\mathrm{H}_{2} \mathrm{O}-\mathrm{DMSO}$ & 293.4 (46 472); 448.4 (6543) & $339.5 ; 358.0(293)$ & 6150 & $0.61 \times 10^{-2}$ \\
\hline \multirow[t]{2}{*}{4} & $\mathrm{ACN}$ & 250.5 (36340); 291.5 (39395); 450.5 (5125) & $355.6(292)$ & 6184 & $4.24 \times 10^{-2}$ \\
\hline & $\mathrm{H}_{2} \mathrm{O}-\mathrm{DMSO}$ & 292.9 (34 083); 448.0 (4822) & $339.0 ; 361.8(293)$ & 6502 & $0.25 \times 10^{-2}$ \\
\hline \multirow[t]{2}{*}{$\mathbf{L}$} & $\mathrm{ACN}$ & $250.0(17215) ; 290.0(21030)$ & $342.6(290)$ & 5294 & $8.27 \times 10^{-2}$ \\
\hline & $\mathrm{H}_{2} \mathrm{O}-\mathrm{DMSO}$ & $291.8(23043)$ & $366.0(292)$ & 6948 & $3.70 \times 10^{-2}$ \\
\hline
\end{tabular}




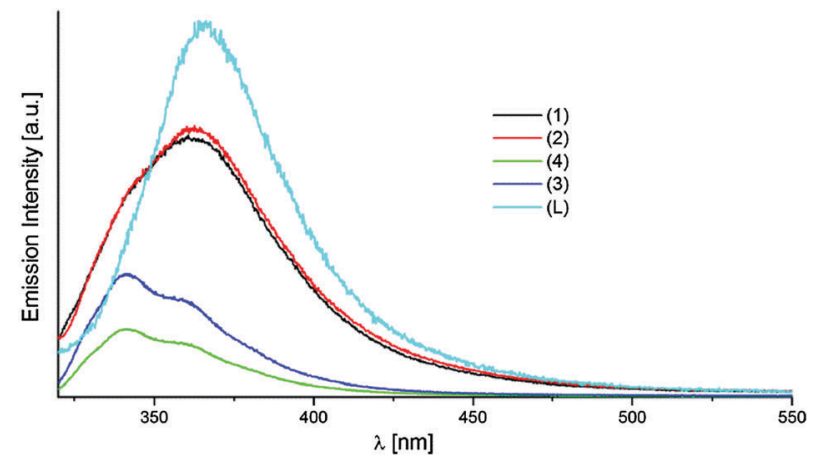

Fig. 9 Emission spectra of $2 \%$ aqueous DMSO solutions of $\mathbf{1 - 4}$ complexes and ligand $\mathbf{L}$ at room temperature.

highest in acetonitrile solution for all studied compounds. The quantum efficiencies of $\mathbf{1}$ and $\mathbf{2}$ are a little higher than those of 3 and 4.

\section{Cytotoxic activity}

MTT assay is a standard in vitro test which is commonly used for the evaluation of the cytotoxicity of chemical compounds. The metabolic activity of compounds is assessed by the cells' ability to reduce the yellow, water soluble tetrazolium salt to water insoluble, purple crystals of formazan. The basis of this concept is that tetrazolium salts can only be reduced by NAD(P)H oxidoreductase enzymes in living cells. ${ }^{42}$ A decrease of absorbance of MTT dye (in the cellular environment of the tested compound) compared with the control sample corresponds to a loss of metabolic activity of cells. This measurement gives basic information about the cytotoxicity of the tested compound. More complete information concerning the effects of tested compounds on the organism is accomplished by comparing its toxicity against cancer cell lines as well as non-cancer cells. This allows us to determine the selectivity of compounds. Therefore, in our studies three cell lines were used: epithelial cervix adenocarcinoma cells HeLa, epithelial mammary gland cells T-47D and nonneoplastic fibroblasts HaCat. ${ }^{43}$ Helicates were applied to cells as solutions with concentrations varying from 1 to $100 \mu \mathrm{M}$ and incubated for $24 \mathrm{~h}$.

The cytostatic effect is expressed as the value of half maximal inhibitory concentration $\left(\mathrm{IC}_{50}\right)$ and presented in Table 3 . The cytotoxic effect of helicates 1-4 is visible against both cancer cell lines, HeLa and T-47D. Interestingly, the $\mathrm{IC}_{50}$ parameters are lower in comparison to that of cisplatin. ${ }^{44}$ In all cases a dosedependent antiproliferative activity may be observed.

In general, one is able to observe an almost two times greater cytotoxic effect of $\mathrm{Ag}(\mathrm{I})$ complexes (overall $\mathrm{IC}_{50}=23.7 \mu \mathrm{M}$ ) than $\mathrm{Cu}(\mathrm{I})$ compounds (overall $\mathrm{IC}_{50}=49.2 \mu \mathrm{M}$ ) towards all three cell lines. In particular, complex 2 seems to exhibit the most prominent cytotoxic effect ( $\mathrm{IC}_{50}$ value oscillates around $14 \mu \mathrm{M}$ ), while complex 3 is the least active (average $\mathrm{IC}_{50}=50 \mu \mathrm{M}$ ) (Fig. 10). The differences among complexes comprising the same metal ions may be related to the counterions used in the syntheses, since they may have an impact on the permeability through cell membranes.
Table 3 The cytotoxicity effects of complexes on HaCat, T-47D and HeLa cell lines. The concentration of compounds that cause a $50 \%$ reduction in cell growth after $24 \mathrm{~h}$ of incubation $\left(I C_{50}\right)$. The $I C_{50}$ value of the ligand is above $100 \mu \mathrm{M}$

\begin{tabular}{|c|c|c|c|}
\hline \multirow[b]{2}{*}{ Complex } & \multicolumn{3}{|c|}{$\underline{\mathrm{IC}_{50} \pm \mathrm{SE}^{a}[\mu \mathrm{M}]}$} \\
\hline & HaCat & T-47D & HeLa \\
\hline 1 & $37.3 \pm 0.2$ & $17.6 \pm 0.3$ & $48.1 \pm 0.4$ \\
\hline 2 & $13.5 \pm 0.3$ & $10.8 \pm 0.2$ & $18.4 \pm 0.3$ \\
\hline 3 & $49.5 \pm 0.2$ & $44.2 \pm 0.4$ & $57.1 \pm 0.1$ \\
\hline 4 & $36.0 \pm 0.1$ & $62.2 \pm 0.2$ & $33.3 \pm 0.2$ \\
\hline
\end{tabular}

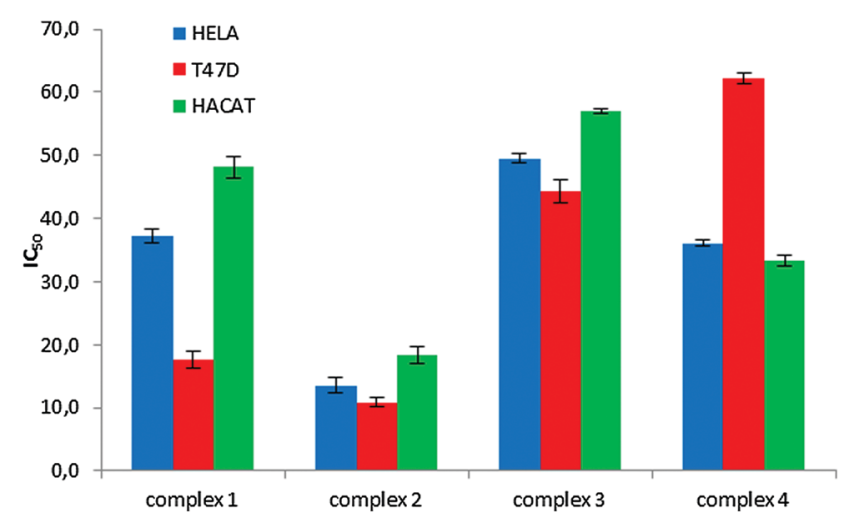

Fig. 10 Comparison of $\mathrm{IC}_{50}$ between HeLa, T-47D and HaCat cell lines. The vertical bars indicate $95 \%$ confidence interval.

Referring to our previous study on the cytotoxicity of $2,2^{\prime}: 6^{\prime}, 2^{\prime \prime}$-terpyridine (tpy) complexes of Ag(I) it is worth noting that the cell growth-inhibitory properties of quaterpyridine (qpy) complexes are slightly weaker towards T-47D and HeLa cells. The comparison of Ag(I) complexes with triflate anions $\left[\mathrm{Ag}_{2}(\mathrm{tpy})_{2}\right](\mathrm{OTf})_{2}$ and $\left[\mathrm{Ag}_{2}(\mathrm{qtp})_{2}\right](\mathrm{OTf})_{2}$ (complex 1) indicates 3-4 times higher cytotoxicity of the tpy complex towards HeLa and T-47D cells. ${ }^{36}$ It may be attributed to the increased size of cations of qpy complexes which may make the permeability through membranes more difficult. 2,2'-Bipyridine, 2,2' $: 6^{\prime}, 2^{\prime \prime}$-terpyridine and 1,10phenanthroline ligands are often used as ancillary ligands for the construction of bioactive complexes due to their electronic properties and chemical inertness (in terms of the formation of covalent bondings and stability). ${ }^{45,46}$

Detailed spectroscopic DNA binding studies and cell cycle analysis were performed to gain further insight into the mechanistic aspects of action of $\mathrm{Ag}(\mathrm{I})$ and $\mathrm{Cu}(\mathrm{I})$ complexes presented in this work.

\section{Apoptosis necrosis assay by flow cytometry}

In general, flow cytometry provides the analysis of the cell cycle based on measuring of the DNA content in a living cell in order to determine whether the effect of analyzed compounds is caused by the inhibition of cell growth or inducing apoptosis. Thus, in general, one may say that any interferences of the cell cycle observed by flow cytometry are DNA dependent. Spectroscopic measurements showed the high demand of complexes to bind with DNA in vitro. Flow cytometry allowed one to observe a similar 


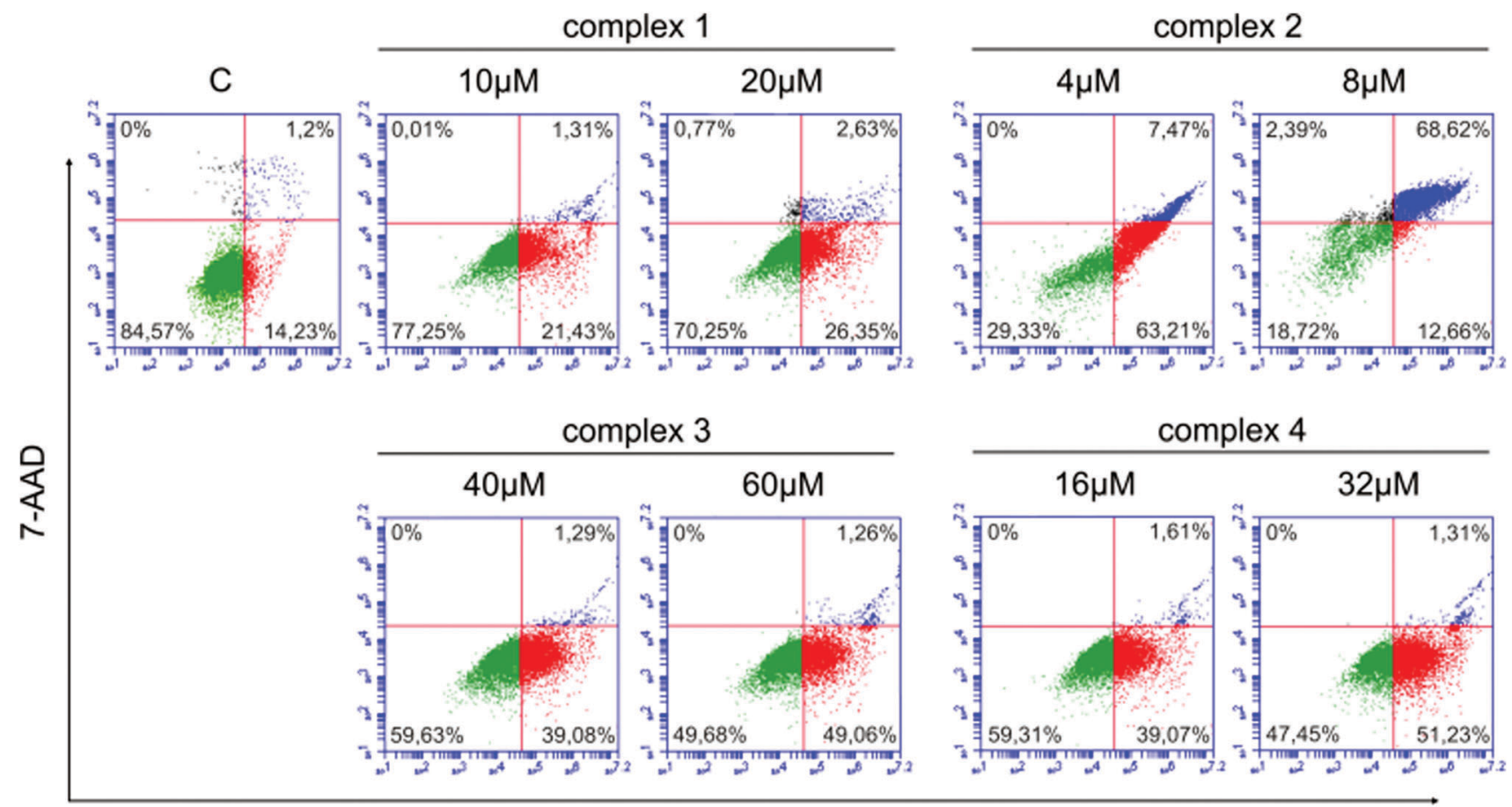

\section{Casp3-FIT C}

Fig. 11 Analysis of cell death induction by $\mathrm{Ag}(\mathrm{I})$ and $\mathrm{Cu}(\mathrm{l})$ complexes by flow cytometry. HeLa cells were exposed to complexes 1-4, and the level of apoptosis was evaluated by dual staining using Casp 3/7-FITC/7-AAD, and analyzed by flow cytometry. The lower left quadrant represents alive, unstained cells. The lower right quadrant represents cells undergoing early apoptosis, showing a positive Casp 3/7-FITC signal. While apoptosis proceeds, the cell membrane became less integral, which results in labeling also with 7-AAD (upper right quadrant).

phenomenon in living cells. This experiment allows one to determine the type of cell death by the utilization of two DNA dyes: CellEvent Caspase 3/7-FITC and 7AAD. CellEvent Caspase 3/7-FITC intercalates into the DNA helix only if the caspase is active which is equivalent/corresponding to apoptosis. The 7AAD dye binds to DNA only in the case of violation of the integrity of cell membranes which corresponds to the late apoptosis or necrosis phenomenon. Normally, in order to sustain the homeostasis cells undergo the programmed death pathway called apoptosis. It may occur as a normal reaction of a healthy organism or as a defense mechanism in the healing processes. While another type of cell death called necrosis may be triggered by some external factors or disease.

An interesting tendency for presented helicates could be observed. In fact, the analysis of cell death induction by complexes 1-4 showed that $\mathbf{3}$ and $\mathbf{4}$ tend to trigger apoptosis of HeLa and T-47D cells (around $40-50 \%$ of the cell population) rather than necrosis $( \pm 1.3 \%)$ (Fig. 11-13). On the other hand, in cases of $\mathbf{1}$ and $\mathbf{2}$ the trend is reversed, which is especially visible for complex 2 (at $8 \mu \mathrm{M}$ concentration) where almost $70 \%$ of cells undergo necrosis. One may assume that the in vivo acceptable redox potential of $\mathrm{Cu}$ ions allows them to interfere with the cell cycle. The activity of $\mathrm{Cu}$ complexes turns out to be in accordance with previously reported studies. ${ }^{47}$

\section{DNA binding properties}

It is well known that DNA is the primary target of many anticancer drugs. ${ }^{48}$ These compounds may interact with the DNA

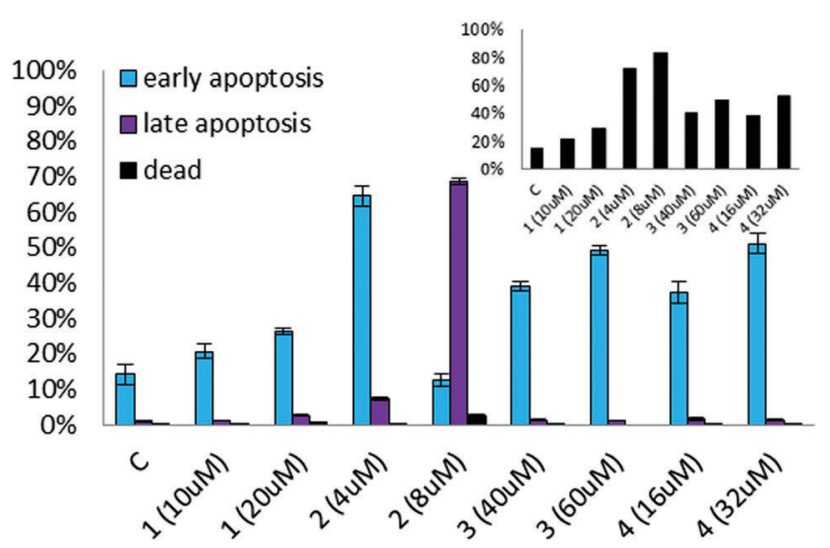

Fig. 12 The graphical representation of the distribution of the types of HeLa cell death. Inset: The amount of dead cells in total.

helix in various manners. They may covalently bind to DNA bases, intercalate between base-pairs, non-specifically bind to the sugarphosphate backbone or attach in the minor or major grooves. ${ }^{49,50}$ The study of the type of interactions between molecules and the DNA helix is of great importance in order to understand the possible mechanism of their biological activity. The binding mode determines the reversibility, strength and specificity of drugs' cytotoxic action in nuclei. Herein, we have attempted to explore the nature of complex-DNA interactions by the molecular docking approach and the circular dichroism technique 


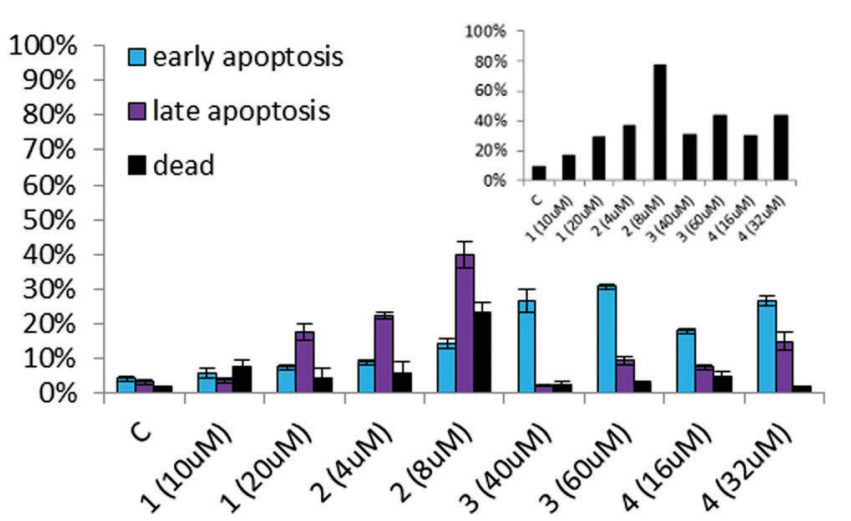

Fig. 13 The graphical representation of the distribution of the types of T-47D cell death. Inset: The amount of dead cells in total.

supported by the fluorescence titration of the CT-DNA-EB complex and DNA melting experiments, as well as NMR studies of the helixes incubated with the HeLa cell extract. It was followed by the investigation of the cells death pathway by means of flow cytometry.

\section{Docking studies of copper(I) complexes in a DNA oligomer}

The docking of helicates with the double-stranded d(CCCCGGGG) DNA was performed to understand the nature of its interactions with DNA and to predict its binding modes. Both complexes were successfully docked into the minor and major grooves of the DNA octamer. Ligand poses were scored by CDOCKER interaction energy and the most favorable orientations, with the highest scores, are shown in Fig. 14 for complex 3 and Fig. 15 for complex 4.

It was found that complex 3 , in its preferred orientations, binds slightly stronger to the minor groove than to the major groove. The corresponding CDOCKER interaction energies are -75.7 and $-68.2 \mathrm{kcal} \mathrm{mol}^{-1}$. For complex 4 the highest scored poses have similar values of CDOCKER interaction energies both in major and minor grooves, which are -74.1 and $-73.3 \mathrm{kcal} \mathrm{mol}^{-1}$, respectively.

The analysis of short contacts between the complexes and DNA shows that cationic helicates $\mathbf{3}$ and $\mathbf{4}$ may bind to DNA

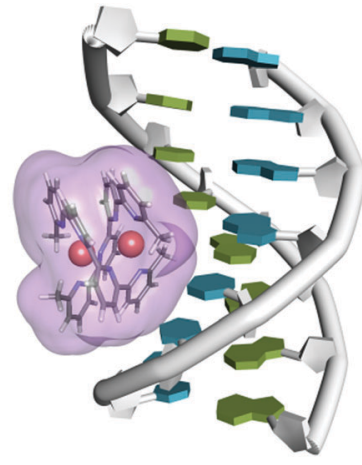

(a) $($ score $=-68.2 \mathrm{kcal} / \mathrm{mol})$

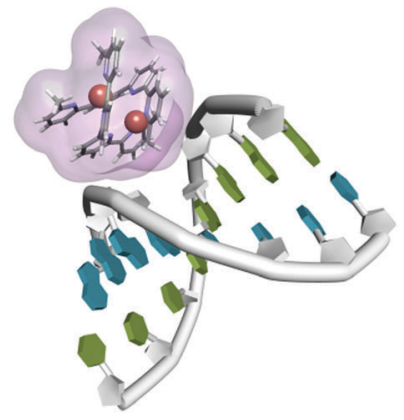

(b) $($ score $=-75.7 \mathrm{kcal} / \mathrm{mol})$
Fig. 14 The highest scored poses of 3 docked into d(CCCCGGGG) DNA (a) in the major groove and (b) in the minor groove.

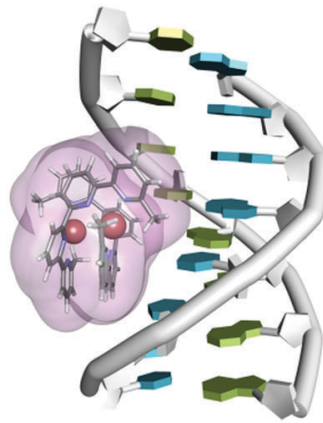

(a) $($ score $=-74.1 \mathrm{kcal} / \mathrm{mol})$

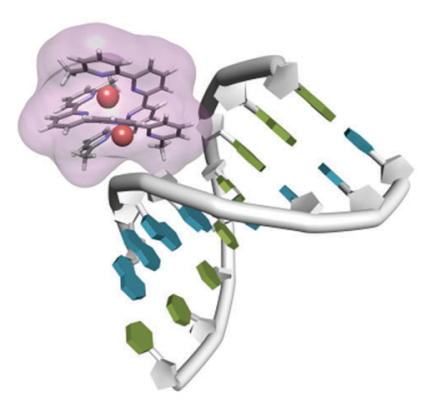

(b) $($ score $=-73.3 \mathrm{kcal} / \mathrm{mol})$
Fig. 15 The highest scored poses of $\mathbf{4}$ docked into d(CCCCGGGG) DNA (a) in the major groove and (b) in the minor groove.

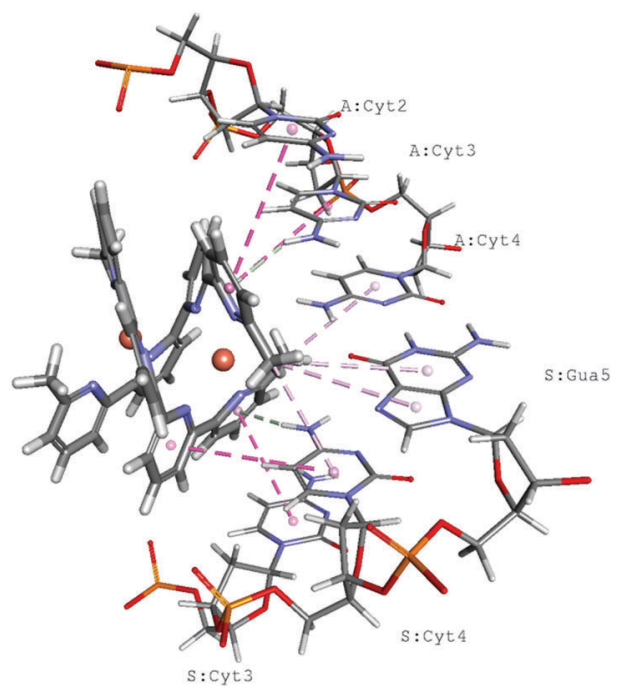

Fig. 16 Specific interactions of complex 3 with d(CCCCGGGG) DNA in the major groove $(\pi-\pi \mathrm{T}$-shaped in magenta, $\pi$-alkyl in light green and $\pi$-hydrogen bond donor in light gray).

through non-covalent van der Waals interactions and electrostatic interactions with negatively charged DNA's sugar-phosphate backbone. In the major groove the complexes form specific hydrophobic interactions with aromatic rings of nucleobases, e.g. $\pi-\pi$ T-shaped, $\pi$-alkyl and $\pi$-hydrogen bond donor (Fig. 16).

van der Waals and electrostatic interactions of the ligands' pyridine rings and $\mathrm{Cu}(\mathrm{I})$ with the DNA phosphate groups are responsible for binding in the minor groove (Fig. 17).

\section{DNA binding investigation via $\mathrm{CD}$}

The CD spectroscopic technique is a sensitive and informative method for monitoring the conformational changes in the DNA helix. In this study we have used a B-DNA strand which exhibits two conservative bands at $240 \mathrm{~nm}$ due to its helicity and at $260 \mathrm{~nm}$ due to $\pi-\pi$ stacking between the base pairs. In general, groove binding and electrostatic interactions show small or no perturbation in CD spectra, whereas the intercalation may induce prominent changes in the intensities of both these bands. ${ }^{51}$ 


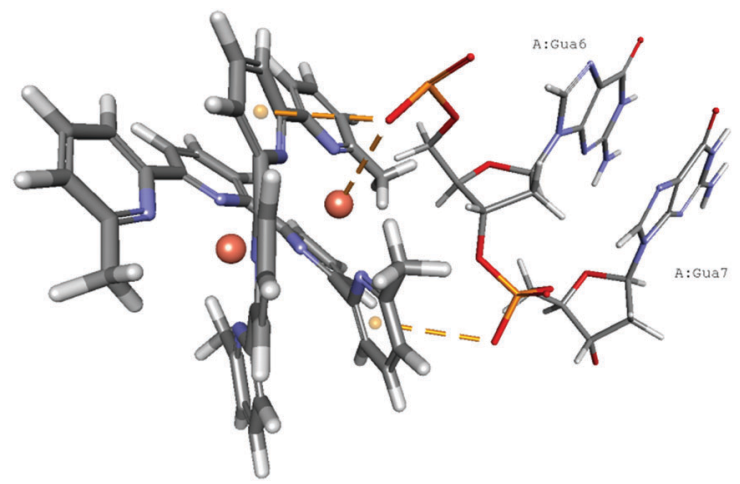

Fig. 17 Specific interactions of complex 4 with d(CCCCGGGG) DNA in the minor groove ( $\pi$-anion in orange, attractive charge interaction in red).

Therefore, the CD spectra of the d(CCCCGGGG) helix were recorded in the absence and presence of increasing concentrations of all complexes in the phosphate buffer at $\mathrm{pH}=7.25$ in the molar ratios of 1,2 and 4 .

All complexes generate some structural changes in the B-DNA ribbon (Fig. 18). The positive band at $260 \mathrm{~nm}$ slightly decreases in cases of complexes 2-4. This suggests that no significant perturbations in the DNA structure occur and most probably it is related to binding in the grooves and stabilizing the helix. These results may be nicely supported by the molecular docking studies for compounds 3 and $\mathbf{4}$, which revealed that mentioned molecules are able to bind in the grooves or interact electrostatically with the surface of the B-DNA helix.

On the other hand, prominent changes may be observed for complex 1. The negative band at $240 \mathrm{~nm}$ is hypsochromically shifted for about $10 \mathrm{~nm}$ and the positive band at $260 \mathrm{~nm}$ decreases upon addition of the complex. It may be concluded as a distortion of the B-DNA caused by another kind of interactions with the complex resulting in attaching tightly to DNA. Evidence supporting this theory might be two additional negative bands visible at ca. 280 and $330 \mathrm{~nm}$ which may be generated due to the connection of a further chromophore to the helix. ${ }^{52}$

According to the experimental results one may assume similar behavior of complexes 2-4 in the presence of DNA in terms of the interaction nature. The changes are indicative of a non-intercalative mode of binding of these complexes and offer support to their groove binding nature. Only complex 1 behaves differently and no straightforward correlations with performed theoretical calculations may be done.
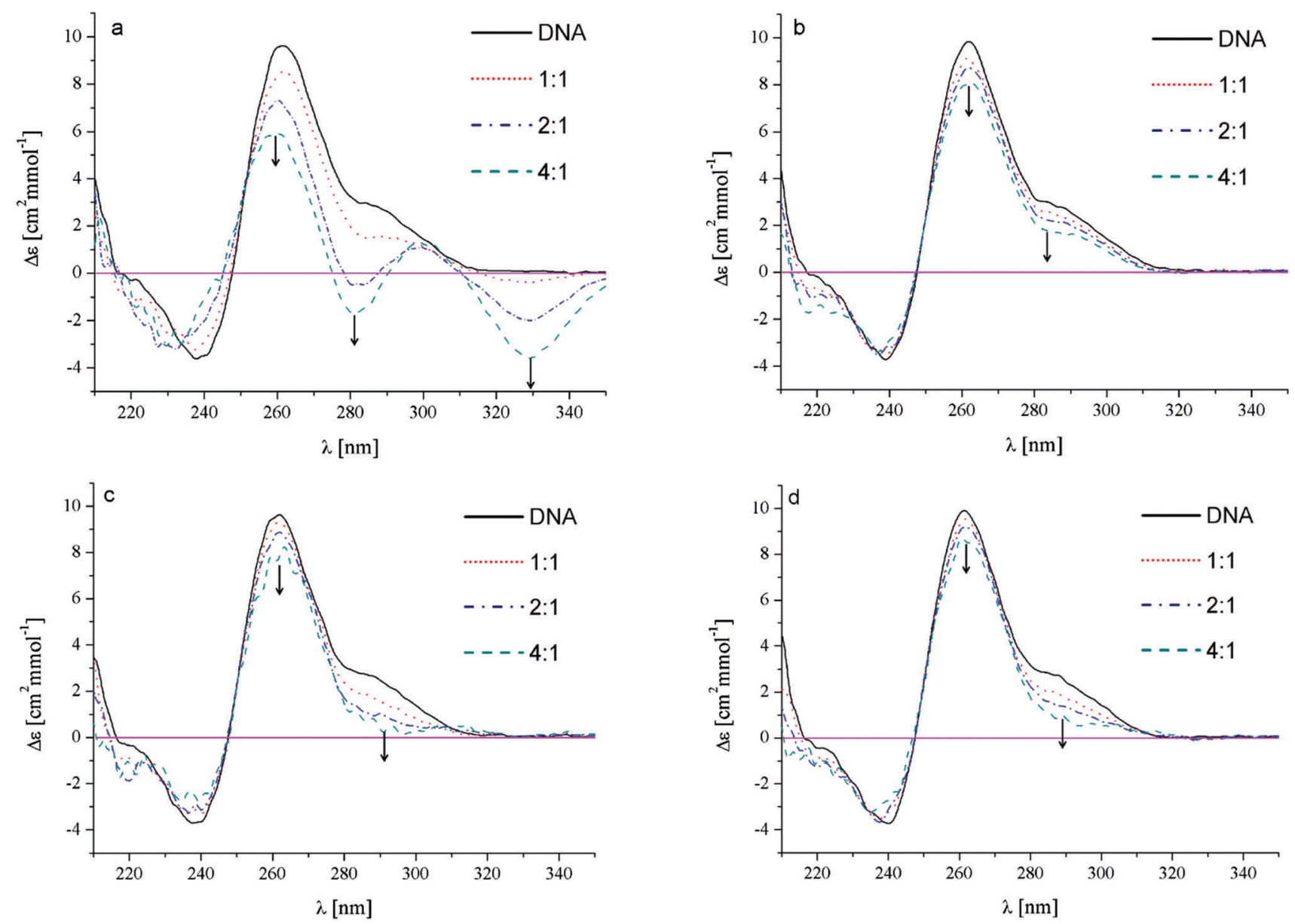

Fig. 18 Circular dichroism spectra of d(CCCCGGGG) in the absence or presence of increasing amounts of complexes $\mathbf{1}$ (a), 2 (b), 3 (c) and $\mathbf{4}$ (d). The arrows indicate the trend of the spectral changes upon addition of complexes. 


\section{Competitive binding with ethidium bromide}

In order to further investigate the interaction mode of investigated complexes with DNA the competitive binding experiments with ethidium bromide (EB) as a probe were carried out. EB is a weak luminescent compound exhibiting high affinity to the DNA helix. Formation of a DNA-EB complex enhances its emission at $\sim 610 \mathrm{~nm}\left(\lambda_{\text {exc }}=467 \mathrm{~nm}\right)$ due to strong intercalation of EB planar phenanthridine ring between adjacent base pairs of the DNA helix. Displacement of EB from its DNA-EB complex due to gradual titration by a competing molecule results in subsequent quenching of its emission band. When the diminution of emission is lower than $50 \%$ one may conclude that, in fact, the compounds do not competitively intercalate the DNA. It may also occur to some extent when groove binders are added to the system. In performed experiments the ratios of $[\mathrm{drug}] /[\mathrm{DNA}]$ were lower than 100 and it caused only about $\sim 30 \%$ emission decrease and did not go any further after addition of another aliquot of complexes (Fig. 19). ${ }^{53}$ Obtained results seem to support the groove binding concept withdrawn from docking studies and CD titrations. Here as well one may observe the specific behavior of complex 1 in the presence of DNA. Two bands arising at around 580 and $680 \mathrm{~nm}$ may be attributed to its strong affinity to the DNA helix ( $c f .3 .7 .2)$.

\section{DNA melting}

Heating of the duplex DNA solutions leads to the increase of its absorbance at $260 \mathrm{~nm}$ due to the dissociation of the double helix. The inflection point of the sigmoidal melting curve is the melting temperature $T_{\mathrm{m}}$. Obtained temperature indicates the thermal stability of the helix.

In general, intercalators and groove binders stabilize the helix and increase the $T_{\mathrm{m}}$ values. These kinds of interactions stabilize the second order structure of the DNA helix. Helicates presented in our study slightly increase the $T_{\mathrm{m}}$ values $\left(2.6-6{ }^{\circ} \mathrm{C}\right)$ of the 12-mer (Table 4). It may support the concept concerning

Table 4 Melting temperatures $T_{m}$ of $d$ (GGGGGGCCCCCC) DNA incubated with complexes. DNA oligomers $T_{m}=60.1{ }^{\circ} \mathrm{C}$

\begin{tabular}{lllll}
\hline Compound & Complex 1 & Complex 2 & Complex 3 & Complex 4 \\
\hline$T_{\mathrm{m}}\left[{ }^{\circ} \mathrm{C}\right]$ & 65.9 & 65.1 & 62.7 & 66.1
\end{tabular}
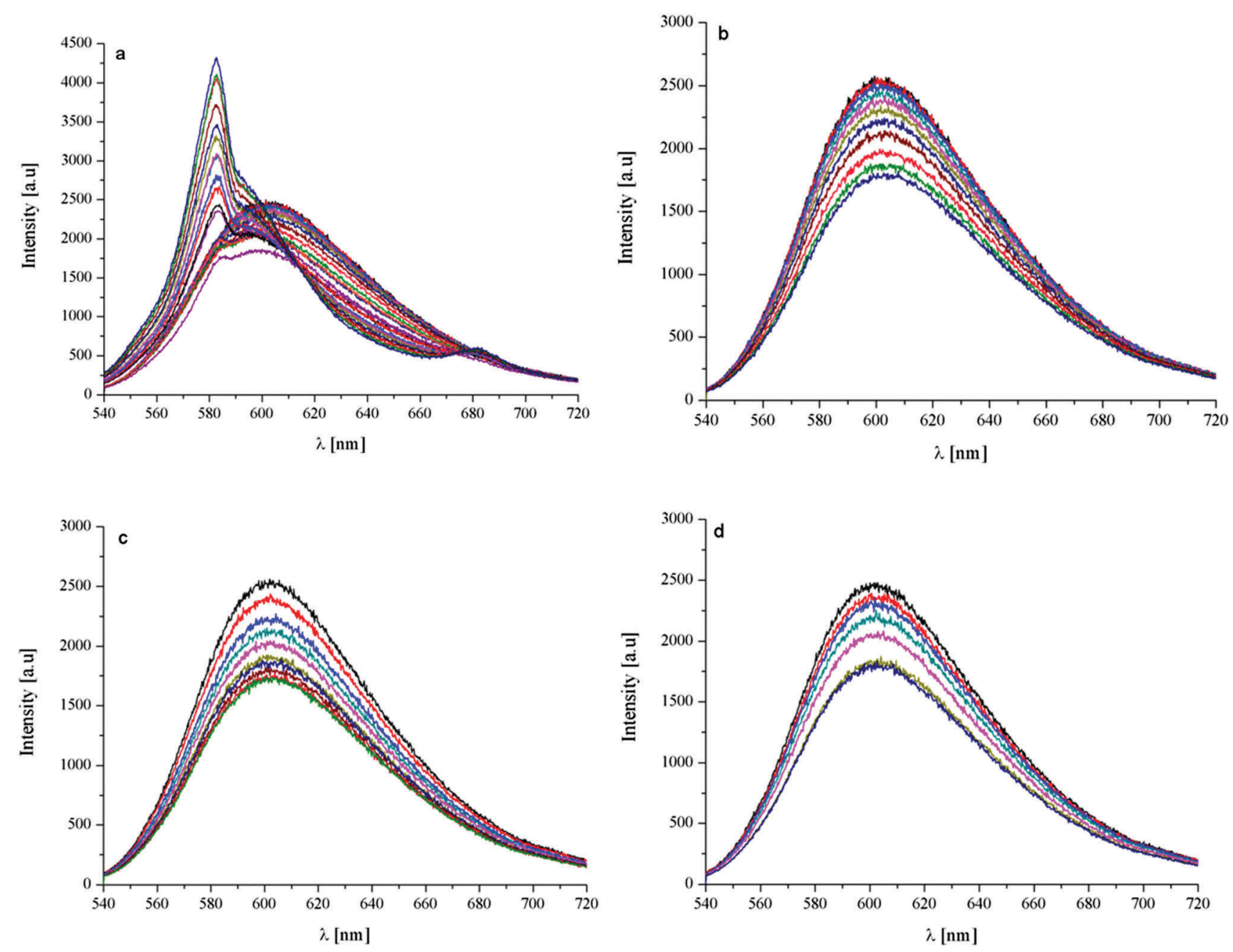

Fig. 19 Emission spectra of EB bound to CT DNA in the presence of increasing amounts of complexes 1-4 (a-d, respectively). 


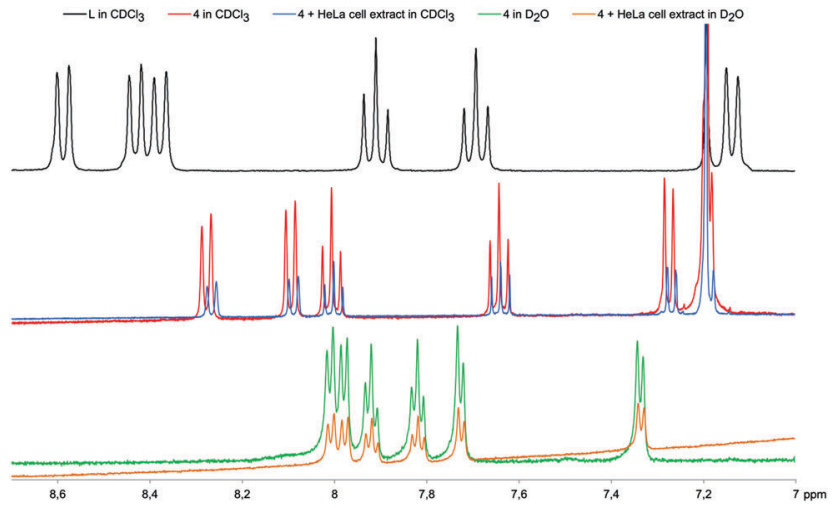

Fig. 20 An aromatic region of NMR spectra of ligand $L$ and its helicate 4 before and after incubation with the HeLa cell extract.

groove binding and may suggest that the binding phenomenon is of moderate strength. ${ }^{54}$

\section{Proton NMR studies of helicates in the HeLa cell extract}

In order to further investigate the stability of complexes in cells NMR spectra in the HeLa cell extract were performed.

In general, ${ }^{1} \mathrm{H}$ NMR reference spectra of free helicates performed in $\mathrm{D}_{2} \mathrm{O}$ as well as in $\mathrm{CDCl}_{3}$ show a set of seven signals corresponding to 36 protons of two ligand strands wrapped around metal ions in a helical complex. In the aromatic region of spectra 1-4 one of the most downfield doublet turns out to be strongly upfield, below the shifts of both triplets, as compared to the ligands' NMR spectrum, which is characteristic of the helical arrangement of ligand molecules in the complex.

${ }^{1} \mathrm{H}$ NMR reference spectra of free helicates overlap with the spectra of helicates after incubation in the HeLa cell extract. The signals in the spectra of free helicates were found to be slightly shifted by $0.02 \mathrm{ppm}$ as compared to the spectra of helicates incubated with the cell extract which is likely due to the presence of deionized water in studied samples (Fig. 20). The spectra of incubated helicates 1-4 performed in $\mathrm{D}_{2} \mathrm{O}$ do not reveal significant changes, which suggests the stability of complexes and resistance against the action of enzymes in the cell extract.

Proton NMR studies of organic layers obtained by the extraction of incubated helicates with $\mathrm{CDCl}_{3}$ were aimed to reveal the presence of a de-coordinated ligand ( $\mathbf{L}$ is very soluble in deuterated chloroform). The proton NMR spectra of organic layers do not reveal even trace amounts of ligand, which is in agreement with previous studies.

\section{Conclusions}

Self-assembly and molecular recognition play key roles both in the synthesis of helicates 1-4 as well as in terms of their behavior in the biological context. The dinuclear double stranded helicates 1-4 were obtained as the result of the self-assembly of $6,6^{\prime \prime \prime \prime}$-dimethyl-2, $2^{\prime} ; 6^{\prime}, 2^{\prime \prime} ; 6^{\prime \prime}, 2^{\prime \prime \prime}$-quaterpyridine $\mathbf{L}$ with tetrahedral ions of $\mathrm{Ag}(\mathrm{I})$ and $\mathrm{Cu}(\mathrm{I})$. The formation of the helical core in complexes 1-4 is a privileged and inherent process and is determined by the interaction of $\mathbf{L}$ with the tetrahedral geometry of metal ions. This type of counterion is less significant, especially considering the behavior of the complexes in solution. ${ }^{1} \mathrm{H}$ NMR shows the stability of each helicate in water as well as in two percent aqueous DMSO solution which play the role of media in biological studies.

The evaluation of the biological activity of the resulting compounds was carried out with a focus on their cytotoxic properties. Their biological potential was investigated via MTT assay towards HeLa, T-47D and HaCaT cell lines. It was further investigated by flow cytometry and one was able to observe the DNA dependent mechanism of cytotoxic action. Moreover, it allowed one to observe that $\mathrm{Ag}(\mathrm{I})$ complexes induce the necrosis of cells while $\mathrm{Cu}(\mathrm{I})$ complexes lead to apoptosis. We find that it is due to the redox properties of metal ions chosen for this study. The redox potential of $\mathrm{Cu}$ ions is acceptable in vivo so that it may have an impact on the bioavailability of the complexes. It needs to be mentioned that the preferred form is $\mathrm{Cu}(\mathrm{I})$ for presented helicates which we showed in NMR studies with the cell extract.

Since the mechanism of action of helicates is most likely related to their interaction with DNA comprehensive studies of its mode were performed. The results obtained by the circular dichroism (CD) technique, competitive binding fluorescence measurements, as well as DNA melting allowed one to anticipate the groove binding mode. This was further supported by molecular docking studies.

Taking into account the reversible redox nature of $\mathrm{Cu}(\mathrm{I})$ helicates the radical activity of these complexes in the cells may become an interesting topic for future studies in our research group.

\section{Experimental section}

\section{General}

$6,6^{\prime \prime \prime}$-Dimethyl-2, $2^{\prime} ; 6^{\prime}, 2^{\prime \prime} ; 6^{\prime \prime}, 2^{\prime \prime \prime}$-quaterpyridine ligand $\mathbf{L}$ was prepared in our laboratory. ${ }^{35}$ All reagents, including metal salts and organic solvents, necessary to carry out the synthesis of complexes 1-4, were used without further purification as supplied from Aldrich Chemical Company. RPMI-1640, DMEM, fetal bovine serum solution, vitamin solution, antibiotic antimycotic solution and PBS were supplied by Sigma. CT-DNA was dissolved in Tris Buffer ( $5 \mathrm{mM}$ Tris $\mathrm{HCl}, 50 \mathrm{mM} \mathrm{NaCl}, \mathrm{pH} 7.3$ ) prior to use. The CT-DNA solution gave a ratio of UV absorbance of $1.82: 1$ at 260 and $280 \mathrm{~nm}$, indicating that the CT-DNA sample was sufficiently free from protein. CT-DNA concentration per nucleotide was determined from the UV absorbance at $260 \mathrm{~nm}$ using the extinction coefficient $\varepsilon_{260}=6600 \mathrm{dm}^{3} \mathrm{~mol}^{-1} \mathrm{~cm}^{-1}$. 55

ESI-MS mass spectra were determined using a Waters Micromass ZQ spectrometer in acetonitrile. The samples were run in positive-ion and negative-ion modes. The concentrations of the compounds were about $10^{-4} \mathrm{~mol} \mathrm{dm}^{-3}$. Sample solutions were introduced into the mass spectrometer source using a syringe pump with a flow rate of $40 \mu \mathrm{L} \mathrm{min}^{-1}$ with a capillary voltage of $+3 \mathrm{kV}$ and a desolvation temperature of $300{ }^{\circ} \mathrm{C}$. The source temperature was $120^{\circ} \mathrm{C}$. Cone voltage $\left(V_{\mathrm{c}}\right)$ was set to $30 \mathrm{~V}$ to allow the transmission of ions without fragmentation processes. 
Scanning was performed from $\mathrm{m} / \mathrm{z}=100$ to 1500 for $6 \mathrm{~s}$, and 10 scans were summed to obtain the final spectrum. ${ }^{1} \mathrm{H}$ NMR spectroscopic data were run on a Varian Gemini $400 \mathrm{MHz}$ spectrometer and were calibrated against the residual protonated solvent signals (DMSO- $\left.\mathrm{d}_{6}: 2.51\left({ }^{1} \mathrm{H}\right)\right)$ with chemical shifts represented in ppm. Microanalyses were performed using a Perkin Elmer $2400 \mathrm{CHN}$ microanalyser. FT-IR spectra were obtained using a Perkin Elmer 580 spectrophotometer and peak positions are reported in $\mathrm{cm}^{-1}$. Optical density was measured using an Eppendorf BioPhotometer. All electronic absorption spectra were recorded using a Shimadzu UVPC 2001 spectrophotometer, between 220 and $800 \mathrm{~nm}$, in $10 \times 10 \mathrm{~mm}$ quartz cells using solutions $\sim 2 \times 10^{-5} \mathrm{M}$ with respect to the metal ions. Luminescence characterization was performed on a Hitachi F-7000 fluorescence spectrophotometer equipped with a xenon lamp $(150 \mathrm{~W})$ which acts as the light source for steady state measurements. For accuracy of data, emission spectra were corrected for the instrumental response. All measurements were carried out under the same experimental conditions. Emission quantum yields were determined by comparison of the integrated emission intensity with that of anthracene ${ }^{56}$ under identical conditions (exciting wavelengths, optical density, apparatus parameters).

\section{General procedure for the synthesis of 1-4}

To a solution of ligand $\mathbf{L}(60.0 \mathrm{mg}, 177 \mu \mathrm{mol})$ in dichloromethane $(10 \mathrm{~mL})$ was added corresponding salt $(177 \mu \mathrm{mol})$ previously dissolved in a $1: 1(\mathrm{v}: \mathrm{v})$ mixture of methanol and acetonitrile $(10 \mathrm{~mL})$. The flask was protected from direct light. The reaction was carried out under an argon atmosphere with stirring for $24 \mathrm{~h}$ at room temperature. Then, the excess solvents were removed by evaporation under reduced pressure. The obtained residue was redissolved in methanol. The complex was isolated from the filtrate by precipitation with diethyl ether.

\section{$\mathrm{Ag}_{2} \mathrm{~L}_{2}\left(\mathrm{CF}_{3} \mathrm{SO}_{3}\right)_{2}(1)$}

Complex 1 was prepared according to the general procedure by using $\mathrm{AgCF}_{3} \mathrm{SO}_{3}(45.6 \mathrm{mg}, 177 \mu \mathrm{mol})$. The resulting product was dried under vacuum to yield $81.3 \mathrm{mg}(77 \%)$ of white crystalline powder. Single crystals suitable for X-ray crystallography were obtained by slow diffusion of diisopropyl ether into a methanol solution of complex $\mathbf{1}$ at lowered temperature.

${ }^{1} \mathrm{H}$ NMR $\left(\mathrm{D}_{2} \mathrm{O}\right.$ : DMSO-d ${ }_{6}, 2 \%$ solution, $\left.400 \mathrm{MHz}\right): \delta(\mathrm{ppm})=$ $8.11(\mathrm{~d}, 4 \mathrm{H}, J=8.01 \mathrm{~Hz}), 8.03(\mathrm{t}, 4 \mathrm{H}, J=7.85 \mathrm{~Hz}), 7.94(\mathrm{~d}, 4 \mathrm{H}, J=$ $7.69 \mathrm{~Hz}), 7.84(\mathrm{~d}, 8 \mathrm{H}, J=4.33 \mathrm{~Hz}), 7.26(\mathrm{t}, 4 \mathrm{H}, J=4.33 \mathrm{~Hz}), 1.81$ $(\mathrm{s}, 12 \mathrm{H})$. ESI-MS(+) (\%): $445(100)[\mathrm{AgL}]^{+}, 1042(5)\left[\mathrm{Ag}_{2} \mathbf{L}_{2}\left(\mathrm{CF}_{3} \mathrm{SO}_{3}\right)\right]^{+}$. Anal calc. for $\left[\mathrm{Ag}_{2}\left(\mathrm{C}_{22} \mathrm{H}_{18} \mathrm{~N}_{4}\right)_{2}\right]\left(\mathrm{CF}_{3} \mathrm{SO}_{3}\right)_{2}$ (1) (1190.68): C, 46.40; H, 3.05; N, 9.41; found: C, 46.37; H, 3.04; N, 9.41\%. IR (KBr, $\left.\mathrm{cm}^{-1}\right)$ : 3573, 3522, 3079, 2916, 1600, 1591, 1569, 1469, 1448, 1386, $1277,1269,1226,1161,1107,1032,1010,793,750,745,653$, $638,573,518$.

$\mathrm{Ag}_{2} \mathrm{~L}_{2}\left(\mathrm{PF}_{6}\right)_{2}$ (2)

Complex 2 was prepared according to the general procedure by using $\mathrm{AgPF}_{6}(44.8 \mathrm{mg}, 177 \mu \mathrm{mol})$. The resulting product was dried under vacuum to yield $79.7 \mathrm{mg}$ (76\%) of white crystalline powder. Single crystals suitable for X-ray crystallography were obtained by slow diffusion of tert-butyl methyl ether into a methanol solution of complex 2 at lowered temperature.

${ }^{1} \mathrm{H}$ NMR $\left(\mathrm{D}_{2} \mathrm{O}\right.$ : DMSO- $\mathrm{d}_{6} ; 2 \%$ solution, $\left.400 \mathrm{MHz}\right): \delta(\mathrm{ppm})=$ $8.13(\mathrm{~d}, 4 \mathrm{H}, J=8.03 \mathrm{~Hz}), 8.05(\mathrm{t}, 4 \mathrm{H}, J=7.83 \mathrm{~Hz}), 7.87(\mathrm{~d}, 4 \mathrm{H}, J=$ $7.69 \mathrm{~Hz}), 7.55(\mathrm{~d}, 8 \mathrm{H}, J=4.61 \mathrm{~Hz}), 7.28(\mathrm{t}, 4 \mathrm{H}, J=4.29 \mathrm{~Hz}), 1.83$ (s, 12H). ESI-MS(+) (\%): 445 (100) [AgL $]^{+}, 1037(3)\left[\mathrm{Ag}_{2} \mathbf{L}_{2}\left(\mathrm{PF}_{6}\right)\right]^{+}$. Anal calc. for $\left[\mathrm{Ag}_{2}\left(\mathrm{C}_{22} \mathrm{H}_{18} \mathrm{~N}_{4}\right)_{2}\right]\left(\mathrm{PF}_{6}\right)_{2}$ (2) (1182.48): C, 44.69; H, 3.07; N, 9.48; found:C, 44.68; H, 3.08; N, 9.46\%. IR (KBr, $\left.\mathrm{cm}^{-1}\right)$ : 3650, 6413, 3081, 2920, 2004, 1928, 1824, 1731, 1632, 1593, 1572, 1469, 1447, 1387, 1303, 1253, 1191, 1176, 1134, 1110, 1004, 850, 792, 745, 653, 638, 558, 502, 483.

\section{$\mathrm{Cu}_{2} \mathrm{~L}_{2}\left(\mathrm{CF}_{3} \mathrm{SO}_{3}\right)_{2}(3)$}

Complex 3 was prepared according to the general procedure by using $\left[\mathrm{Cu}(\mathrm{MeCN})_{4}\right] \mathrm{CF}_{3} \mathrm{SO}_{3}(55.8 \mathrm{mg}, 177 \mu \mathrm{mol})$. The resulting product was dried under vacuum to yield $81.5 \mathrm{mg}(94 \%)$ of red crystalline powder. Single crystals suitable for X-ray crystallography were obtained by slow diffusion of tert-butyl methyl ether into a methanol solution of complex 3 at lowered temperature.

${ }^{1} \mathrm{H}$ NMR $\left(\mathrm{D}_{2} \mathrm{O}\right.$ : DMSO- $\mathrm{d}_{6} ; 2 \%$ solution, $\left.400 \mathrm{MHz}\right): \delta(\mathrm{ppm})=$ $7.95(\mathrm{~m}, 8 \mathrm{H}), 7.85(\mathrm{t}, 4 \mathrm{H}, J=7.76 \mathrm{~Hz}), 7.73(\mathrm{t}, 4 \mathrm{H}, J=7.84 \mathrm{~Hz})$, $7.63(\mathrm{~d}, 4 \mathrm{H}, J=7.48 \mathrm{~Hz}), 7.24(\mathrm{~d}, 4 \mathrm{H}, J=7.48 \mathrm{~Hz}), 1.80(\mathrm{~s}, 12 \mathrm{H})$. ESI-MS(+) (\%): 402 (100) [CuL $]^{+}, 953(8)\left[\mathrm{Cu}_{2} \mathbf{L}_{2}\left(\mathrm{CF}_{3} \mathrm{SO}_{3}\right)\right]^{+}$. Anal calc. for $\left[\mathrm{Cu}_{2}\left(\mathrm{C}_{22} \mathrm{H}_{18} \mathrm{~N}_{4}\right)_{2}\right]\left(\mathrm{CF}_{3} \mathrm{SO}_{3}\right)_{2}$ (3) (1102.04): C, 50.13; H, 3.29; N, 10.17; found: C, 50.10; H, 3.29; N, 10.16\%. IR (KBr, $\left.\mathrm{cm}^{-1}\right)$ : 3424, 3069, 2921, 2006, 1915, 1830, 1742, 1605, 1595, 1565, 1472, 1446, 1388, 1380, 1257, 1248, 1183, 1175, 1063, 1013, 918, 831, $824,788,752,734,654,640,533,522,489$.

$\mathrm{Cu}_{2} \mathrm{~L}_{2}\left(\mathrm{BF}_{4}\right)_{2}$ (4)

Complex 4 was prepared according to the general procedure by using $\left[\mathrm{Cu}(\mathrm{MeCN})_{4}\right] \mathrm{BF}_{4}(55,7 \mathrm{mg}, 177 \mu \mathrm{mol})$. The resulting product was dried under vacuum to yield $76.2 \mathrm{mg}(78 \%)$ of red crystalline powder. Single crystals suitable for X-ray crystallography were obtained by slow diffusion of tert-butyl methyl ether into a methanol solution of complex 4 at lowered temperature.

${ }^{1} \mathrm{H}$ NMR $\left(\mathrm{D}_{2} \mathrm{O}\right.$ : DMSO- $\mathrm{d}_{6} ; 2 \%$ solution, $\left.400 \mathrm{MHz}\right): \delta(\mathrm{ppm})=$ $7.93(\mathrm{~m}, 8 \mathrm{H}), 7.84(\mathrm{t}, 4 \mathrm{H}, J=7.76 \mathrm{~Hz}), 7.73(\mathrm{t}, 4 \mathrm{H}, J=7.85 \mathrm{~Hz})$, $7.62(\mathrm{~d}, 4 \mathrm{H}, J=7.48 \mathrm{~Hz}), 7.25$ (d, $4 \mathrm{H}, J=7.48 \mathrm{~Hz}), 1.80(\mathrm{~s}, 12 \mathrm{H})$. ESI-MS(+) (\%): $402(100)[\mathrm{CuL}]^{+}, 990(6)\left[\mathrm{Cu}_{2} \mathbf{L}_{2}\left(\mathrm{BF}_{4}\right)\right]^{+}$. Anal calc. for $\left[\mathrm{Cu}_{2}\left(\mathrm{C}_{22} \mathrm{H}_{18} \mathrm{~N}_{4}\right)_{2}\right]\left(\mathrm{BF}_{4}\right)_{2}$ (4) (977.51): C, 54.06; H, 3.71; N, 11.46; found: C, 54.04; H, 3.70; N, 11.45\%. IR (KBr, $\left.\mathrm{cm}^{-1}\right): 3569$, 3475, 3076, 3036, 2963, 2918, 2292, 1984, 1902, 1824, 1734, $1606,1595,1571,1473,1449,1389,1278,1264,1223,1186$, 1156, 1106, 1090, 1030, 1013, 792, 749, 655, 637, 573, 554, 518.

\section{Crystal structure determination of 1-4}

Diffraction data were collected by the $\omega$-scan technique on Agilent Technologies four-circle diffractometers: 1 at 130(1) K on a SuperNova with an Atlas CCD detector, equipped with a Nova microfocus $\mathrm{CuK}_{\alpha}$ radiation source $(\lambda=1.54178 \AA$ ) , 2-4 at $100(1) \mathrm{K}$ on an Xcalibur with an Eos CCD detector and graphitemonochromated $\mathrm{MoK}_{\alpha}$ radiation $(\lambda=0.71069 \AA)$. The data were corrected for Lorentz-polarization as well as for absorption effects. $^{57}$ Precise unit-cell parameters were determined by a 
Table 5 Crystal data, data collection and structural refinement

\begin{tabular}{|c|c|c|c|c|}
\hline Compound & 1 & 2 & 3 & 4 \\
\hline Formula & $\mathrm{C}_{44} \mathrm{H}_{36} \mathrm{Ag}_{2} \mathrm{~N}_{8}{ }^{2+} \cdot 2\left(\mathrm{CF}_{3} \mathrm{SO}_{3}\right)^{-}$ & $\mathrm{C}_{44} \mathrm{H}_{36} \mathrm{Ag}_{2} \mathrm{~N}_{8}{ }^{2+} \cdot 2\left(\mathrm{PF}_{6}\right)^{-}$ & $\mathrm{C}_{44} \mathrm{H}_{36} \mathrm{Cu}_{2} \mathrm{~N}_{8}{ }^{2+} \cdot 2\left(\mathrm{CF}_{3} \mathrm{SO}_{3}\right)^{-}$ & $\mathrm{C}_{44} \mathrm{H}_{36} \mathrm{Cu}_{2} \mathrm{~N}_{8}{ }^{2+} \cdot 2\left(\mathrm{BF}_{4}\right)^{-} \cdot 2\left(\mathrm{C}_{7} \mathrm{H}_{8}\right) \cdot \mathrm{CH}_{3} \mathrm{OH}$ \\
\hline Formula weight & $1190.69 / c$ & 1182.49 & 1102.03 & 1193.81 \\
\hline Crystal system & Monoclinic & Monoclinic & Monoclinic & Orthorhombic \\
\hline$a(\AA)$ & $16.0589(3)$ & $12.5733(4)$ & $23.7716(18)$ & $14.1499(10)$ \\
\hline$b(\AA)$ & $15.5077(3)$ & $23.2638(6)$ & $13.2745(8)$ & $16.6539(10)$ \\
\hline$c(\AA)$ & $18.1719(7)$ & $16.2128(5)$ & $31.455(3)$ & $22.4487(13)$ \\
\hline$Z$ & 4 & 4 & 8 & 4 \\
\hline$D_{x}\left(\mathrm{~g} \mathrm{~cm}^{-3}\right)$ & 1.76 & 1.67 & 1.66 & 1.50 \\
\hline$F(000)$ & 2384 & 2352 & 4480 & 2456 \\
\hline$\mu\left(\mathrm{mm}^{-1}\right)$ & 8.58 & 0.99 & 1.15 & 0.88 \\
\hline$\Theta$ range $\left(^{0}\right)$ & $3.75-70.0$ & $2.98-28.07$ & $2.90-25.0$ & $3.26-25.0$ \\
\hline \multicolumn{5}{|l|}{ Reflections: } \\
\hline Collected & 9002 & 9658 & 29719 & 12631 \\
\hline $\mathrm{w} R\left(F^{2}\right)$ [all data] & 0.148 & 0.093 & 0.117 & 0.27 \\
\hline Goodness of fit & 1.28 & 1.10 & 0.99 & 1.08 \\
\hline 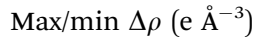 & $1.89 /-1.31$ & $1.07 /-0.68$ & $0.86 /-0.51$ & $0.70 /-0.53$ \\
\hline
\end{tabular}

least-squares fit of 7649 (1), 2957 (2), 5305 (3), and 4311 (4) reflections of the highest intensity, chosen from the whole experiment. The structures were solved using $\operatorname{SIR}^{2} 2^{58}$ and refined by the full-matrix least-squares procedure on $F^{2}$ using SHELXL-2013. ${ }^{59}$ All non-hydrogen atoms were refined anisotropically, hydrogen atoms were placed in idealized positions and refined as a 'riding model' with isotropic displacement parameters set at 1.2 (1.5 for methyl or hydroxyl groups) times $U_{\text {eq }}$ of appropriate carrier atoms.

In 1 the $\mathrm{CF}_{3} \mathrm{SO}_{3}$ anion is disordered over two sites (s.o.f.'s refined at $0.705(6) / 0.295(6))$. In 2 in turn the $\mathrm{PF}_{6}$ anion is also disordered (0.684(6)/0.316(6)); moreover, relatively large diffused residual electron density was interpreted for disordered solvent molecules and the SQUEEZE procedure was applied. Also in 3, one of the $\mathrm{CF}_{3} \mathrm{SO}_{3}$ anions is disordered (0.503(5)/0.497(5)). In all the three structures the rigid-bond (RIGU) and similarity (SIMU) restraints have been applied. Finally, in $\mathbf{4}$ a solvent, methanol, molecule was found to be disordered across the center of symmetry.

Table 5 lists the relevant experimental data and refinement details. Crystallographic data (excluding structural factors) for the structural analysis have been deposited with the Cambridge Crystallographic Data Centre, CCDC 1060683-1060686 (1-4).

\section{Cell cultures}

Cells were seeded onto 96-well plates at a density of $1 \times$ $10^{4}$ cells per well in the growth medium and incubated until $70-80 \%$ confluency. On the next day the cells were treated with complexes 1-4 at a final concentration of 1-100 $\mu \mathrm{M}$. After $24 \mathrm{~h}$ incubation, MTT assay was used to estimate cell viability. Cells were incubated in the presence of $0.5 \mathrm{mg}$ MTT per $\mathrm{mL}$ (final concentration) for $1 \mathrm{~h}$ at $37^{\circ} \mathrm{C}$. After incubation formazan crystals were dissolved in DMSO. The absorbance was read at $570 \mathrm{~nm}$.
The amount of formazan produced by cells is proportional to the number of live and metabolically active cells.

\section{Cytotoxicity tests in cancer cell lines}

In particular, the assay is based on the cellular reduction of MTT [3-(4,5-dimethylthiazol-2-yl)-2,5-diphenyltetrazolium bromide] by the mitochondrial dehydrogenase of viable cells to water insoluble blue crystals. HeLa, T-47D and HaCat cell lines were cultured in 96-well plates in $100 \mathrm{~mL}$ of medium (RPMI-1640 or DMEM, both supplemented with $10 \%$ FBS), $1 \%$ of antibiotic antimycotic solution and $1 \%$ of RPMI-1640 vitamin solution at a density of $4 \times 10^{4}$ cells $\mathrm{mL}^{-1}$ and incubated for $24 \mathrm{~h}$ at $37^{\circ} \mathrm{C}$ and $5 \% \mathrm{CO}_{2}$. All complexes were dissolved in 2\% DMSO water solution and added to wells at final concentrations ranging from 0 to $100 \mu \mathrm{M}$. After $48 \mathrm{~h}$ MTT was added to each well (final concentration $5 \mathrm{mg} \mathrm{mL}^{-1}$ ) and the plates were further incubated for $2 \mathrm{~h}$ at $37^{\circ} \mathrm{C}$ in a $5 \% \mathrm{CO}_{2}$ atmosphere. After the incubation period the remaining crystals were dissolved in $100 \mathrm{~mL}$ of DMSO. The absorption of the resultant solutions was measured using a Biotek Synergy 2 MultiMode Plate Reader at 590 and $670 \mathrm{~nm}$. All cytotoxicity tests were performed in triplicate. $\mathrm{The} \mathrm{IC}_{50}$ values were calculated from curves constructed by plotting cell survival (\%) versus compound concentration (in $\mathrm{mM}$ ).

\section{Statistical analysis}

All results of MTT assay are means of three separate tests of six reps. The statistical analysis was performed using Statistica 12 software (StatSoft, inc., Tulsa, USA). The results were reported as the mean \pm standard error (SE) values or $\pm 95 \%$ confidence interval values. The data were analyzed by one-way analysis of variance with Duncan and Dunnett as post hoc tests. Differences between $\mathrm{IC}_{50}$ with $p$ value $<0.05$ were considered to be statistically significant. 


\section{Apoptosis necrosis assay by flow cytometry}

Apoptosis necrosis assay was performed by double staining with Cellevent Caspase-3/7 Green-FITC (ThermoFisher Scientific) and 7-AAD (BD Pharmingen) fluorescent dyes. Briefly, cells $\left(5 \times 10^{5}\right)$ were seeded onto 6-well plates. On the next day cells were treated for $24 \mathrm{~h}$ with complex $1(10,20 \mu \mathrm{M})$, complex $2(4,8 \mu \mathrm{M})$, complex 3 $(40,60 \mu \mathrm{M})$ and complex $4(16,32 \mu \mathrm{M})$. The concentrations were adjusted to the $\mathrm{IC}_{50}$ values of complexes towards distinct cell lines. Subsequently cells were detached with trypsin (Sigma-Aldrich) and washed twice with $1 \mathrm{~mL}$ of PBS and stained using Caspase 3/7-FITC and 7-AAD according to manufacturer's protocol. Cells were analyzed immediately after staining, with $488 \mathrm{~nm}$ excitation using an Accuri C6 flow cytometer (Becton Dickinson).

\section{DNA binding experiments}

Docking studies. Canonical B-DNA of the 8-mer duplex d(CCCCGGGG) was built in Discovery Studio $4.1^{60}$ using the Built and Edit Nucleic Acid tool. The duplex consists of two strands S (sense strand) and A (antisense strand). Subsequently, the DNA octamer was minimized using the adopted basis Newton-Raphson minimization algorithm $(\max$ steps $=5000$, RMS gradient $\left.=0.01 \mathrm{kcal}(\mathrm{mol} \AA)^{-1}\right)$ and the implicit solvent model (generalized Born with molecular volume (GBMV) with implicit solvent dielectric constant $\varepsilon=80$ ). X-ray structures of complex 3 and complex 4 cations were optimized using the DFT method. The standard double- $\xi$ LANL2DZ basis set, associated with a pseudopotential, was used for $\mathrm{Cu}$ atoms, and 6-31G(d,p) was used for other atoms. All DFT calculations were carried out using the B3LYP functional in Gaussian09.

The optimized structures of complexes 3 and $\mathbf{4}$ were docked into the major and minor grooves of the DNA octamer. Docking studies were performed using the CDOCKER ${ }^{61}$ procedure implemented in Discovery Studio 4.1. The binding site sphere was centered in the major or minor grooves and the radius of the sphere was set to a value of $14 \AA$ A. Partial charges for the receptor and ligands were assigned according to Momany-Rone and MMFF94 charging rules, respectively. Cu(I) ions in helicates were treated as cations with the formal and partial charge equal to +1 . CDOCKER uses molecular dynamics to generate ligand conformations, but during docking this step was skipped because the only rotatable bonds in complexes $\mathbf{3}$ and $\mathbf{4}$ are those connecting methyl groups with pyridine rings. For every docking run the starting conformation of each ligand was placed in the binding sphere in ten initial orientations by random rotations and translations. Finally, poses were minimized with full potential, the complete CHARMm force-field expression and up to ten poses were saved for each ligand after docking.

Silver complexes were not docked due to the lack of appropriate parameters in the MMFF94 forcefield for Ag.

Circular dichroism studies. A JASCO J815 spectropolarimeter was used to collect circular dichroism spectra (CD). Quartz cuvettes with a path length of $1 \mathrm{~cm}$ were used with the sample volumes of $2000 \mu \mathrm{L}$. Spectra were collected in the range between 210 and $350 \mathrm{~nm}$ at $25^{\circ} \mathrm{C}$, from three scans and a buffer baseline was subtracted from each spectrum. Circular dichroism was expressed as the difference in the molar absorption of the righthanded and left-handed circularly polarized light. $\Delta_{\varepsilon}$, in units of $\mathrm{cm}^{2} \mathrm{mmol}^{-1}$, was normalized to the number of nucleoside residues in the RNA samples. ${ }^{62}$

For the CD experiments $10 \mu \mathrm{M}$ DNA d(CCCCGGGG) samples were dissolved in $150 \mathrm{mM} \mathrm{NaCl}, 10 \mathrm{mM}$ sodium phosphate and $0.1 \mathrm{mM}$ EDTA (pH 7.25). 10, 20 or $40 \mu \mathrm{M}$ complexes were added 5 min before measurements and the samples were annealed by heating at $70{ }^{\circ} \mathrm{C}$ for $5 \mathrm{~min}$ and then slowly cooled down to room temperature.

Competitive binding fluorescence measurements. The competitive binding of compound with ethidium bromide (EB) has been investigated by the fluorescence emission spectroscopy in order to evaluate its ability to displace EB from its CT-DNA-EB fluorescent complex. The solution of EB $(20 \mu \mathrm{M})$ and CT-DNA $(26 \mu \mathrm{M})$ was allowed to equilibrate for $30 \mathrm{~min}$ at $25{ }^{\circ} \mathrm{C}$ before the measurements were taken. While increasing the concentration of investigated complexes, the fluorescence spectra were recorded in the range of $540-720 \mathrm{~nm}$ at $\lambda_{\mathrm{ex}}=467 \mathrm{~nm}$.

UV melting studies. The concentration of the solution of the d(GGGGGGCCCCCC) oligomer was determined by UV spectrophotometry using the extinction coefficient $\varepsilon=$ $113400 \mathrm{dm}^{3} \mathrm{~mol}^{-1} \mathrm{~cm}^{-1}$ at $260 \mathrm{~nm}$. The DNA sample was annealed at $90{ }^{\circ} \mathrm{C}$ and then slowly cooled down in order to ensure the existence of a double helix in the sample. The UV melting experiment was run on a Jasco V-670 Spectrophotometer, equipped with a Peltier temperature controller. The heating was performed between $25{ }^{\circ} \mathrm{C}$ and $90{ }^{\circ} \mathrm{C}$ and back with a $1{ }^{\circ} \mathrm{C} \mathrm{min}{ }^{-1}$ rate. Spectra were recorded in $1 \times 1 \mathrm{~cm}$ quartz cells.

NMR studies in the HeLa cell extract. HeLa cells were cultured in RPMI-1640 medium supplemented with 10\% fetal bovine serum (FBS), 1× RPMI-1640 vitamin solution and $1 \times$ antibiotic antimycotic solution in $5 \% \mathrm{CO}_{2}$ for $48 \mathrm{~h}$. Then the cells were trypsinized and subsequently washed three times with phosphate buffered saline to remove any remaining trypsin and medium. The cell extract was prepared by sonication of $1.6 \times 10^{7}$ cells in $1 \mathrm{~mL}$ of deionized water with subsequent centrifugation at $20000 \times g$ for $5 \mathrm{~min}$.

The HeLa cell extract corresponding to $1.6 \times 10^{-7}$ cells in $1 \mathrm{~mL}$ of deionized water was prepared according to the literature. ${ }^{63}$ Helicate $(1 \mathrm{mM})$ was added to the HeLa cell extract $(100 \mu \mathrm{L})$ and then the resulting suspension was incubated at $37{ }^{\circ} \mathrm{C}$ for $24 \mathrm{~h}$. In this manner, two separate samples were performed for each complex. After incubation time, the first sample was extracted with $\mathrm{CDCl}_{3}(450 \mu \mathrm{L})$ and the organic layer was studied by ${ }^{1} \mathrm{H}$ NMR. To the second sample $\mathrm{D}_{2} \mathrm{O}$ was added $(350 \mu \mathrm{L})$ and then the resulting solution was studied by proton NMR. Furthermore, proton NMR reference spectra of free helicates were performed in $\mathrm{D}_{2} \mathrm{O}$ and $\mathrm{CDCl}_{3}$ as well. The NMR data were obtained by collection of 900 scans, which turns out to be sufficient to obtain good signal-to-noise ratios.

\section{Acknowledgements}

Circular dichroism studies were done at Adam Mickiewicz University in the Laboratory of Organic Stereochemistry; Prof. Marcin Kwit is gratefully acknowledged. This research 
was carried out as a part of the National Science Center project (Grant No. 2015/19/N/ST5/00615). The results concerning HeLa cell transfection of 1-4 in cell localization were obtained in the Laboratory of Subcellular Structures Analysis, Institute of Bioorganic Chemistry, Polish Academy of Sciences in Poznań. The DFT calculations were performed at the Poznan Supercomputing and Networking Center affiliated with the Institute of Bioorganic Chemistry of the Polish Academy of Sciences, http://www.man.poznan.pl/online/en/.

\section{Notes and references}

1 E. Mattia and S. Otto, Nat. Nanotechnol., 2015, 10, 111-119.

2 C.-Y. Zheng and H. Li, Inorg. Chem. Commun., 2013, 34, 30-33.

3 B. K. Rana, V. Bertolasi, S. Pal, P. Mitra and J. Dinda, J. Mol. Struct., 2013, 1049, 458-463.

4 G. Yuan, L. Rong, C. Yue and X. Wei, Inorg. Chem. Commun., 2013, 33, 19-24.

5 R. Chakravarty, P. S. Mukherjee and P. J. Stang, Chem. Rev., 2011, 111, 6810-6918.

6 C. S. Hawes and P. E. Kruger, Polyhedron, 2013, 52, 255-260.

7 E. C. Constable, C. E. Housecroft, M. Neuburger, S. Reymanna and S. Schaffnera, CrystEngComm, 2008, 10, 991-995.

8 N. G. White, J. A. Kitchen, J. A. Joule and S. Brooker, Chem. Commun., 2012, 48, 6229-6231.

9 H.-Y. Guan, H.-D. Shao, L. Li, J.-M. Jia and F. Guo, J. Chem. Crystallogr., 2013, 43, 471-477.

10 A. Stephenson and M. D. Ward, Chem. Commun., 2012, 48, 3605-3607.

11 C. Piguet, G. Bernardinelli and G. Hopfgartner, Chem. Rev., 1997, 97, 2005-2062.

12 L.-J. Yi, G.-C. Xu, L. Zhang and D.-Z. Jia, Inorg. Chem. Commun., 2014, 45, 36-39.

13 C. R. Rice, C. J. Baylies, H. J. Clayton, J. C. Jeffery, R. L. Paul and M. D. Ward, Inorg. Chim. Acta, 2003, 351, 207-216.

14 C. R. K. Glasson, G. V. Meehan, C. A. Motti, J. K. Clegg, P. Turner, P. Jensen and L. F. Lindoy, Dalton Trans., 2011, 10481-10490.

15 P. K.-K. Ho, S.-M. Peng, K.-Y. Wong and C.-M. Che, J. Chem. Soc., Dalton Trans., 1996, 1829-1834.

16 C.-T. Yeung, H.-L. Yeung, C.-S. Tsang, W.-Y. Wong and H.-L. Kwong, Chem. Commun., 2007, 5203-5205.

17 C. R. Rice, S. Wörl, J. C. Jeffery, R. L. Paul and M. D. Ward, J. Chem. Soc., Dalton Trans., 2001, 550-559.

18 S. M. McNeill, D. Preston, J. E. M. Lewis, A. Robert, K. Knerr-Rupp, D. O. Graham, J. R. Wright, G. I. Giles and J. D. Crowley, Dalton Trans., 2015, 11129-11136.

19 M.-S. Seo, K. Kim and H. Kim, Chem. Commun., 2013, 49, 11623-11625.

20 H. Maeda, T. Nishimura, R. Akuta, K. Takaishi, M. Uchiyama and A. Muranaka, Chem. Sci., 2013, 4, 1204-1211.

21 Q.-Y. Huang, T. Li and X.-R. Meng, Inorg. Chem. Commun., 2014, 49, 52-55.
22 J. A. Castro-Osma, C. Alonso-Moreno, M. V. Gómez, I. Márquez-Segovia, A. Otero, A. Lara-Sánchez, J. FernándezBaeza, L. F. Sánchez-Barba and A. M. Rodríguez, Dalton Trans., 2013, 14240-14252.

23 V. G. Machadoa, P. N. W. Baxter and J.-M. Lehn, J. Braz. Chem. Soc., 2001, 12(4), 431-462.

24 M. Greenwald, D. Wessely, I. Goldberg and Y. Cohen, New J. Chem., 1999, 337-344.

25 M.-T. Li, J.-W. Sun, J.-Q. Sha, H.-B. Wu, E.-L. Zhang and T.-Y. Zheng, J. Mol. Struct., 2013, 1045, 29-34.

26 P. Smoleński, S. W. Jaros, C. Pettinari, G. Lupidi, L. Quassinti, M. Bramucci, L. A. Vitali, D. Petrelli, A. Kochel and A. M. Kirillov, Dalton Trans., 2013, 6572-6581.

27 M. I. Azócar, H. Muñoz, P. Levin, N. Dinamarca, G. Gómez, A. Ibañez, M. T. Garland and M. A. Paez, Commun. Inorg. Synth., 2013, 1, 19-21.

28 K. A. Ali, M. M. Abd-Elzaher and K. Mahmoud, Int. J. Med. Chem., 2013, 256836.

29 A. A. Massoud, V. Langer, Y. M. Gohar, M. A. M. Abu-Youssef, J. Janis, G. Lindberg, K. Hansson and L. Ohrstrom, Inorg. Chem., 2013, 52, 4046-4060.

30 A. I. Ortega-Arizmendi, E. Aldeco-Pérez and E. Cuevas-Yañez, Sci. World J., 2013, 186537.

31 M. Yang, A. S. Jalloh, W. Wei, J. Zhao, P. Wu and P. R. Chen, Nat. Commun., 2014, 5, 4981-4991.

32 A. Ciesielski, V. Patroniak and M. Kubicki, J. Chem. Crystallogr., 2011, 41, 1884-1888.

33 A. Ciesielski, A. R. Stefankiewicz, M. Wałęsa-Chorab, V. Patroniak, M. Kubicki, Z. Hnatejko and J. M. Harrowfield, Supramol. Chem., 2009, 41, 48-54.

34 A. Adamski, M. Wałęsa-Chorab, M. Kubicki, Z. Hnatejko and V. Patroniak, Polyhedron, 2014, 81, 188-195.

35 A. Adamski, M. Kubicki, P. Pawluć, T. Grabarkiewicz and V. Patroniak, Catal. Commun., 2013, 42, 79-83.

36 A. R. Stefankiewicz, M. Wałęsa, P. Jankowski, A. Ciesielski, V. Patroniak, M. Kubicki, Z. Hnatejko, J. M. Harrowfield and J.-M. Lehn, Eur. J. Inorg. Chem., 2008, 2910-2920.

37 M. A. Fik, A. Gorczyński, M. Kubicki, Z. Hnatejko, A. FedorukWyszomirska, E. Wyszko, M. Giel-Pietraszuk and V. Patroniak, Eur. J. Med. Chem., 2014, 86, 456-468.

38 M. Wałęsa-Chorab, V. Patroniak, G. Schroeder and R. Frański, Eur. J. Mass Spectrom., 2010, 16, 163-168.

39 J.-L. Chen, X.-F. Fu, J.-Y. Wang, Z.-H. Guo, Y.-L. Xiao, L.-H. He and H.-R. Wen, Inorg. Chem. Commun., 2015, 53, 88-91.

40 C.-L. Ming, Y.-H. Li, G.-Y. Li and G.-H. Cui, Transition Met. Chem., 2014, 39, 477-485.

41 R.-Y. Huang, J.-W. Wang, C. Xue, S.-P. Zhao and H. Xu, Inorg. Chim. Acta, 2014, 423, 133-138.

42 T. Mosmann, J. Immunol. Methods, 1983, 65, 55-63.

43 A. A. Stepanenko and V. V. Dmitrenko, Gene, 2015, 574, 193-203.

44 Y. Liu, H. Xing, X. Han, X. Shi, F. Liang, G. Cheng, Y. Lu and D. Ma, J. Huazhong Univ. Sci. Technol., Med. Sci., 2008, 28, 197-199.

45 S. Banerjee, A. Dixit, K. Maheswaramma, B. Maity, S. Mukherjee, A. Kumar, A. Karande and A. R. Chakravarty, J. Chem. Sci., 2016, 128, 165-175. 
46 L. Kucková, K. Jomová, A. Švorcová, M. Valko, P. Segía, J. Moncoí and J. Kožíšek, Molecules, 2015, 20, 2115-2137.

47 V. M. Manikandamathavan and B. U. Nair, Eur. J. Med. Chem., 2013, 68, 244-252.

48 X.-Z. Wang, J.-H. Yao, G.-B. Jiang, J. Wang, H.-L. Huang and Y.-J. Liu, Spectrochim. Acta, Part A, 2014, 133, 559-567.

49 L. Cerasino, M. J. Hannon and E. Sletten, Inorg. Chem., 2007, 46, 6245-6251.

50 B.-L. Fei, W.-S. Xu, H.-W. Tao, W. Li, Y. Zhang, J.-Y. Long, Q.-B. Liu, B. Xia and W.-Y. Sun, Photochem. Photobiol., 2014, 132, 36-44.

51 L. Li, Q. Guo, J. Dong, T. Xu and J. Li, J. Photochem. Photobiol., B, 2013, 125, 56-62.

52 A. Lauria, R. Bonsignore, A. Terenzi, A. Spinello, F. Giannici, A. Longo, A. M. Almerico and G. Barone, Dalton Trans., 2014, 6108-6119.

53 A. Moodi, M. Khorasani-Motlagh, M. Noroozifar and S. Niroomand, J. Biomol. Struct. Dyn., 2013, 937-950.
54 W. Hu, C. Blecking, M. Kralj, L. Suman, I. Piantanida and T. Schrader, Chem. - Eur. J., 2012, 18, 3589-3597.

55 M. E. Reichmann, S. A. Rice, C. A. Thomas and P. Doty, J. Am. Chem. Soc., 1954, 76, 3047-3053.

56 D. F. Eaton, Pure Appl. Chem., 1988, 60, 1107-1114.

57 Agilent Technologies, CrysAlis PRO (Version 1.171.33.36d), Agilent Technologies Ltd, 2011.

58 A. Altomare, G. Cascarano, C. Giacovazzo and A. Guaraldi, J. Appl. Crystallogr., 1993, 26, 343-350.

59 G. M. Sheldrick, Acta Crystallogr., 2015, C71, 3-8.

60 DassaultSystèmes BIOVIA, Discovery Studio Modeling Environment, Release 4.1, DassaultSystèmes, San Diego, 2014.

61 G. Wu, D. H. Robertson, C. L. Brooks III and M. Vieth, J. Comput. Chem., 2003, 24, 1549-1562.

62 T. R. Sosnick, X. Fang and V. M. Shelton, Methods Enzymol., 2000, 317, 393-409.

63 M. Malgowska, D. Gudanis, R. Kierzek, E. Wyszko, V. Gabelica and Z. Gdaniec, Nucleic Acids Res., 2014, 42(15), 10196-10207. 